\title{
Below the Callus Surface: Applying Paleohistological Techniques to Understand the Biology of Bone Healing in Skeletonized Human Remains
}

\author{
Sandra Assis ${ }^{a} \quad$ Anne Keenleyside ${ }^{b}$ \\ ${ }^{a}$ CIAS - Research Centre for Anthropology and Health, Department of Life Sciences, University of Coimbra, \\ Coimbra, Portugal; ' bepartment of Anthropology, Trent University, Peterborough, Ont., Canada
}

\author{
Key Words \\ Paleohistopathology · Biology of fracture healing . \\ Osteomyelitis · Age-related osteopenia · Posttraumatic \\ interval $\cdot$ Bone remodeling
}

\begin{abstract}
Objectives: Bone trauma is a common occurrence in human skeletal remains. Macroscopic and imaging scrutiny is the approach most currently used to analyze and describe trauma. Nevertheless, this line of inquiry may not be sufficient to accurately identify the type of traumatic lesion and the associated degree of bone healing. To test the usefulness of histology in the examination of bone healing biology, we used an integrative approach that combines gross inspection and microscopy. Materials and Methods: Six bone samples belonging to 5 adult individuals with signs of bone trauma were collected from the Human Identified Skeletal Collection from the Museu Bocage (Lisbon, Portugal). Previous to sampling, the lesions were described according to their location, morphology, and healing status. After sampling, the bone specimens were prepared for plane light and polarized light analysis. Results: The histological analysis was pivotal: (1) to differentiate between types of traumatic lesions; (2) to ascertain the posttraumatic interval, and (3) to diag-
\end{abstract}

\section{KARGER}

E-Mail karger@karger.com www.karger.com/pat nose other associated pathological conditions. Conclusion: The outer surface of a bone lesion may not give a complete picture of the biology of the tissue's response. Accordingly, microscopic analysis is essential to differentiate, characterize, and classify trauma signs.

(c) 2016 S. Karger AG, Basel

\section{Introduction}

Injury constitutes one of the major causes of death and disability worldwide and a source of health and social concern with regard to prevention and treatment [1]. As nowadays, injury has also played a significant role in past human societies, a role that can be accessed through a careful analysis of the skeletal remains [2]. Bone injury, resulting from interpersonal violence or associated with the hazards of daily life, is frequently reported in the paleopathological literature as a useful tool to decipher past behaviors and health conditions [3-14]. The prevalence and distribution of fractures constitute the marker most commonly investigated [15-20]. The study of fractures in the skeletonized remains relies on the macroscopic and radiological identification of signs of bone healing [21-23] and allied complications such as bone shortening, deformity, infection,
(C) 2016 S. Karger AG, Basel

1015-2008/16/0834-0177\$39.50/0 
Table 1. List of the bone samples extracted for microscopic analysis from the Human Identified Skeletal Collection from the Museu Bocage (Lisbon, Portugal)

\begin{tabular}{|c|c|c|c|c|c|c|}
\hline \multirow[t]{2}{*}{ Sk. } & \multicolumn{3}{|c|}{ Individual profile } & \multicolumn{3}{|l|}{ Bone sample } \\
\hline & $\operatorname{sex}$ & $\begin{array}{l}\text { age at death, } \\
\text { years }\end{array}$ & cause of death & $\begin{array}{l}\text { bone } \\
\text { element }\end{array}$ & location & $\begin{array}{l}\text { length, } \\
\mathrm{cm}\end{array}$ \\
\hline 54 & M & 23 & Pulmonary tuberculosis & Right tibia & Mid-shaft & 1.5 \\
\hline 119 & $\mathrm{~F}$ & 64 & Bronchopneumonia & 9th right rib & Sternal end & 2.0 \\
\hline 198 & $\mathrm{M}$ & 68 & Urinary sepsis & Right fibula & Distal diaphysis & 2.0 \\
\hline 1,138 & $\mathrm{M}$ & 86 & Bronchopneumonia & 4th right rib & Middle portion & 1.0 \\
\hline 1,196 & $\mathrm{~F}$ & 75 & Arteriosclerosis & Right rib & Middle portion & 6.0 \\
\hline 1,196 & $\mathrm{~F}$ & 75 & Arteriosclerosis & Right radius & Distal diaphysis & 1.7 \\
\hline
\end{tabular}

and pseudarthrosis, among others [21, 23-25]. As in the clinical context, imaging analysis is considered the best line of inquiry for diagnosing and classifying fractures [26]. Nevertheless, its application may be restricted due to the unavailability of equipment or by the presence of diagenetic bone changes that may bias the radiological interpretation $[23,27]$. As a result, the visual inspection of complete or partial callus formation $[10,15]$ and/or angular deformities [10] constitutes the methodological approach most often used. What about paleohistology? What information concerning bone healing can be gained from the application of histological techniques?

The paleohistopathological analysis of skeletal remains offers a glimpse into the products of cellular activity such as excessive tissue mineralization, signs of abnormal bone resorption, and residual organics associated with past diseases $[28,29]$. Furthermore, it provides a wide range of information with regard to microstructural changes that bone undergoes during burial, and that can affect disease diagnosis [30]. Wright and Yoder [31] stated that the application of histological methods may be especially important for examining the degrees of bone healing, as well as for identifying traces of disease in cases where little bone response occurred prior to death. This assertion is equally shared by Ragsdale and Lehmer [32]: if cells are the effectors of bone changes, understanding their dynamic interaction is a necessary step for the differential diagnosis.

Using two methodological approaches that compare macroscopic and histological observations, this study aims: (1) to describe the macro- and microstructure of the bone callus; (2) to ascertain the biology of bone healing and the posttraumatic survival interval, and (3) to discuss diagnoses by identifying other conditions that might have caused the lesions observed.

\section{Materials and Methods}

Five adult individuals with multiple trauma evidence and housed at the Human Identified Skeletal Collection from the $\mathrm{Mu}$ seu Bocage (Lisbon, Portugal) were chosen for analysis [33]. However, only 6 bone calluses on the ribs and long bones were targeted for sampling (table 1). For skeleton 1,196 (Sk. 1,196), permission was granted to take 2 samples. Due to the invasive nature of the histological procedures, bone sampling was adjusted in order to avoid needless damage to the skeletons. For example, when possible the samples were taken close to damaged areas or in bones showing postmortem breakage. Prior to bone sampling, fractures were classified according to their location, stage of healing and/or presence of bone malalignment. Only lesions that were healing (presence of woven bone near the fracture edges or surrounding the primary callus) or had a healed appearance (presence of sclerotic or dense bone) were considered [22]. After sampling, the bone specimens were prepared for histological analysis [34] as the follows: (1) cleaning and dehydration in water and ethyl alcohol (95\%), respectively; (2) embedding in epoxy resin; (3) sectioning using a slow speed saw; (4) grinding using graded sandpaper discs, and an abrasive slurry of aluminum oxidate; (5) dehydration in ethyl alcohol (95\%), followed by immersion in xylene (vacuum chamber) and (6) microscopic analysis under plane and polarized light. The qualitative description of the callus histomorphology considered the bone tissue involved (periosteum, cortex, or endosteum), the type of bone response observed (resorption, formation, or both), the type of new bone produced (woven, lamellar or both), and the prevalence of osteocyte lacunae.

\section{Results}

\section{Macroscopic Study of the Degree of Bone Healing}

A total of 42 consolidated and unconsolidated bone calluses were observed in the 5 adult individuals considered for analysis (table 2). Of these, $35.7 \%$ (15/42) were seen in the adult male Sk. 1,138 (86 years old), 30.9\% (13/42) in the adult female Sk. 119 (64 years old), and 
Table 2. Distribution of the evidence of bone trauma in the individuals analyzed by bone element, anatomic location, and rate of consolidation

\begin{tabular}{|c|c|c|c|c|c|c|c|c|}
\hline \multirow[t]{2}{*}{ Sk. } & \multicolumn{2}{|c|}{ Individual profile } & \multicolumn{5}{|l|}{ Trauma evidence } & \multirow{2}{*}{$\begin{array}{l}\text { Bone } \\
\text { sample }\end{array}$} \\
\hline & $\operatorname{sex}$ & $\begin{array}{l}\text { age at death, } \\
\text { years }\end{array}$ & number & type & bone element & anatomic location & $\begin{array}{l}\text { rate of } \\
\text { consolidation }\end{array}$ & \\
\hline 54 & M & 23 & Single $(n=1)$ & Bone callus & Right tibia & Mid-shaft & Consolidated & Yes \\
\hline 119 & $\mathrm{~F}$ & 64 & Multiple ( $\mathrm{n}=13$ ) & Bone callus & $\begin{array}{l}\text { Right humerus } \\
\text { Left radius } \\
\text { Right radius } \\
\text { 2nd right rib } \\
\text { 3rd right rib } \\
\text { 7th left rib } \\
\text { 8th left rib } \\
\text { 8th right rib } \\
\text { 9th left rib } \\
\text { 9th right rib } \\
\text { 10th right rib } \\
\text { 11th right rib } \\
\text { Pelvis }\end{array}$ & $\begin{array}{l}\text { Proximal diaphysis } \\
\text { Distal diaphysis } \\
\text { Distal diaphysis } \\
\text { Sternal end } \\
\text { Sternal end } \\
\text { Sternal end } \\
\text { Sternal end } \\
\text { Sternal end } \\
\text { Sternal end } \\
\text { Sternal end } \\
\text { Sternal end } \\
\text { Sternal end } \\
\text { Ischiopubic ramus }\end{array}$ & $\begin{array}{l}\text { Consolidated } \\
\text { Consolidated } \\
\text { Consolidated } \\
\text { Consolidated } \\
\text { Consolidated } \\
\text { Consolidated } \\
\text { Consolidated } \\
\text { Consolidated } \\
\text { Consolidated } \\
\text { Consolidated } \\
\text { Consolidated } \\
\text { Consolidated } \\
\text { Consolidated }\end{array}$ & $\begin{array}{l}\text { No } \\
\text { No } \\
\text { No } \\
\text { No } \\
\text { No } \\
\text { No } \\
\text { No } \\
\text { No } \\
\text { No } \\
\text { Yes } \\
\text { No } \\
\text { No } \\
\text { No }\end{array}$ \\
\hline 198 & M & 68 & Multiple $(\mathrm{n}=3)$ & Bone callus & $\begin{array}{l}\text { Right tibia } \\
\text { Left fibula } \\
\text { Right fibula }\end{array}$ & $\begin{array}{l}\text { Distal diaphysis } \\
\text { Distal diaphysis } \\
\text { Distal diaphysis }\end{array}$ & $\begin{array}{l}\text { Consolidated } \\
\text { Consolidated } \\
\text { Consolidated }\end{array}$ & $\begin{array}{l}\text { No } \\
\text { No } \\
\text { Yes }\end{array}$ \\
\hline 1,138 & M & 86 & Multiple $(\mathrm{n}=15)$ & Bone callus & $\begin{array}{l}\text { 3rd right rib } \\
\text { 4th right rib } \\
\text { 5th left rib } \\
\text { 6th right rib } \\
\text { 7th right rib } \\
\text { 8th right rib } \\
\text { 9th right rib } \\
\text { 10th right rib } \\
\text { 11th right rib }\end{array}$ & $\begin{array}{l}\text { Middle portion } \\
\text { Middle portion } \\
\text { Sternal end } \\
\text { Middle portion } \\
\text { Vertebral end } \\
\text { Middle portion } \\
\text { Sternal end } \\
\text { Middle portion } \\
\text { Vertebral end } \\
\text { Middle portion } \\
\text { Sternal end } \\
\text { Vertebral end } \\
\text { Sternal end } \\
\text { Vertebral end } \\
\text { Vertebral end }\end{array}$ & $\begin{array}{l}\text { Unconsolidated } \\
\text { Unconsolidated } \\
\text { Consolidated } \\
\text { Unconsolidated } \\
\text { Consolidated } \\
\text { Unconsolidated } \\
\text { Consolidated } \\
\text { Unconsolidated } \\
\text { Consolidated } \\
\text { Unconsolidated } \\
\text { Consolidated } \\
\text { Consolidated } \\
\text { Unconsolidated } \\
\text { Consolidated } \\
\text { Consolidated }\end{array}$ & $\begin{array}{l}\text { No } \\
\text { Yes } \\
\text { No } \\
\text { No } \\
\text { No } \\
\text { No } \\
\text { No } \\
\text { No } \\
\text { No } \\
\text { No } \\
\text { No } \\
\text { No } \\
\text { No } \\
\text { No } \\
\text { No }\end{array}$ \\
\hline 1,196 & $\mathrm{~F}$ & 75 & Multiple $(\mathrm{n}=10)$ & Bone callus & $\begin{array}{l}\text { Left radius } \\
\text { Right radius } \\
\text { 8th left rib } \\
\text { 9th left rib } \\
\text { 10th left rib } \\
\text { Right rib } \\
\text { Right fibula }\end{array}$ & $\begin{array}{l}\text { Distal diaphysis } \\
\text { Distal diaphysis } \\
\text { Vertebral end } \\
\text { Middle portion } \\
\text { Vertebral end } \\
\text { Middle portion } \\
\text { Vertebral end } \\
\text { Middle portion } \\
\text { Middle portion } \\
\text { Distal diaphysis }\end{array}$ & $\begin{array}{l}\text { Consolidated } \\
\text { Consolidated } \\
\text { Consolidated } \\
\text { Consolidated } \\
\text { Consolidated } \\
\text { Consolidated } \\
\text { Consolidated } \\
\text { Consolidated } \\
\text { Consolidated } \\
\text { Consolidated }\end{array}$ & $\begin{array}{l}\text { No } \\
\text { Yes } \\
\text { No } \\
\text { No } \\
\text { No } \\
\text { No } \\
\text { No } \\
\text { No } \\
\text { Yes } \\
\text { No }\end{array}$ \\
\hline
\end{tabular}

$23.8 \%(10 / 42)$ in the adult female Sk. 1,196 (75 years old). With the exception of Sk. 54, all the remaining individuals exhibited multiple signs of bone trauma. The majority of the bone calluses were recorded on ribs, mainly in those from the lower segment (R7-R10). For example, 15 bone calluses, 7 of them unconsolidated, were observed in 8 right ribs and in one left rib of the Sk. 1,138 individual.
This individual also showed a combination of healed and unconsolidated fractures in 5 ribs. The other bone calluses were observed in the radii (Sk. 1,196), tibia (Sk. 54), and fibula (Sk. 198).

Of the 6 bone elements selected for histological analysis, 5 presented bone calluses with a consolidated and healed appearance (table 3 ). That is, the calluses appeared 
Table 3. Evaluation of the macroscopic features of the bone callus by individual, bone element, location, and healing stage

\begin{tabular}{|c|c|c|c|c|c|}
\hline Sk. & $\begin{array}{l}\text { Bone } \\
\text { element }\end{array}$ & $\begin{array}{l}\text { Injury } \\
\text { location }\end{array}$ & $\begin{array}{l}\text { Macroscopic description of the bone callus } \\
\text { features }\end{array}$ & $\begin{array}{l}\text { Healing } \\
\text { stage }\end{array}$ & $\begin{array}{l}\text { Complications secondary to bone } \\
\text { healing }\end{array}$ \\
\hline 54 & $\begin{array}{l}\text { Right } \\
\text { tibia }\end{array}$ & Mid-shaft & $\begin{array}{l}\text { Slight elevation of dense bone with an } \\
\text { irregular morphology (>medial surface); } \\
\text { Combination of smooth and rough areas; } \\
\text { Postmortem detachment of the bone outer } \\
\text { surface (>anterior-superior portion of the } \\
\text { bone callus) }\end{array}$ & $\begin{array}{l}\text { Healed } \\
\text { fracture }\end{array}$ & $\begin{array}{l}\text { Slight bowing of the tibia diaphysis, with } \\
\text { minor changes in the geometry of the } \\
\text { affected area; Presence of a small cloaca } \\
(\sim 1 \mathrm{~mm}) \text { with round and remodeled } \\
\text { contours below the callus and on the } \\
\text { anterior surface; Presence of a slight } \\
\text { patch of periosteal new bone formation } \\
\text { in the lateral portion of the bone callus }\end{array}$ \\
\hline 119 & $\begin{array}{l}\text { 9th right } \\
\text { rib }\end{array}$ & $\begin{array}{l}\text { Sternal } \\
\text { end }\end{array}$ & $\begin{array}{l}\text { Mount-shaped elevation of dense bone on the } \\
\text { visceral surface; } \\
\text { Smooth surface; } \\
\text { Some postmortem changes }\end{array}$ & $\begin{array}{l}\text { Healed } \\
\text { fracture }\end{array}$ & No angular deformities were identified \\
\hline 198 & $\begin{array}{l}\text { Right } \\
\text { fibula }\end{array}$ & $\begin{array}{l}\text { Distal } \\
\text { diaphysis }\end{array}$ & $\begin{array}{l}\text { Combination of smooth areas of dense bone } \\
\text { (lateral portion) with small and irregular } \\
\text { deposits of bone with a sharp appearance } \\
\text { (medial portion) }\end{array}$ & $\begin{array}{l}\text { Healed } \\
\text { fracture }\end{array}$ & $\begin{array}{l}\text { Malalignment with overlapping of the } \\
\text { fractured ends; Bone shortening }\end{array}$ \\
\hline 1,138 & $\begin{array}{l}\text { 4th right } \\
\text { rib }\end{array}$ & $\begin{array}{l}\text { Middle } \\
\text { portion }\end{array}$ & $\begin{array}{l}\text { Unhealed complete fracture; } \\
\text { Light-colored fracture ends with an irregular, } \\
\text { sharp and polished morphology; } \\
\text { Presence of woven bone deposits encircling } \\
\text { the injured area (>bony edges) }\end{array}$ & $\begin{array}{l}\text { Unhealed } \\
\text { fracture }\end{array}$ & - \\
\hline 1,196 & $\begin{array}{l}\text { Right } \\
\text { rib }\end{array}$ & $\begin{array}{l}\text { Middle } \\
\text { portion }\end{array}$ & $\begin{array}{l}\text { Slight bone elevation; } \\
\text { Smooth appearance; } \\
\text { Small enlargement of the affected area }\end{array}$ & $\begin{array}{l}\text { Healed } \\
\text { fracture }\end{array}$ & Slight swelling of the affected area \\
\hline 1,196 & $\begin{array}{l}\text { Right } \\
\text { radius }\end{array}$ & $\begin{array}{l}\text { Distal } \\
\text { diaphysis }\end{array}$ & $\begin{array}{l}\text { Possible Colles fracture; } \\
\text { Slight transverse depression on the anterior } \\
\text { surface; } \\
\text { Abnormal amount of bone in the posterior } \\
\text { surface (despite the postmortem damage) }\end{array}$ & $\begin{array}{l}\text { Healed } \\
\text { fracture }\end{array}$ & $\begin{array}{l}\text { Slight deformation of the distal } \\
\text { extremity }\end{array}$ \\
\hline
\end{tabular}

slightly elevated from the bone surface and presented a dense and smooth outer shell. Only the 4 th right rib of the Sk. 1,138 individual showed an unconsolidated callus. Depending on the bone element, the callus morphology ranged from a sharp outlook to a mount-shaped or round relief (e.g. Sk. 119; fig. 1a-d). In 2 individuals (Sk. 54 and Sk. 198), the fracture had introduced slight structural changes in the bone architecture (fig. $2 \mathrm{a}-\mathrm{d}, 3 \mathrm{a}-\mathrm{c}$ ). In the case of the Sk. 198 right fibula, an inefficient stabilization had caused a malalignment of the shaft with an overlap of the broken ends and subsequent bone shortening. In addition to some structural changes, a small cloaca $(\sim 1 \mathrm{~mm})$ with remodeled contours (anterior portion) and a patch of periosteal new bone formation (lateral portion) were observed in the Sk. 54 tibia bone callus. Healed fractures were seen in the ribs and at the distal extremity of the Sk. 1,196 radii, causing a slight epiphysis malalignment (fig. 4a-b2). In the unhealed rib fracture (Sk. 1,138), the broken edges presented an irregular, smooth, and polished morphology. Surrounding the affected area, deposits of periosteal new bone were seen detached from the surface. No 'movable' joint-like structure was identified at the fractured ends (fig. $5 \mathrm{a}-\mathrm{d}$ ).

\section{Histomorphology of the Bone Callus}

The histological analysis of the 6 bone samples showed a well-preserved bone microanatomy with good bone birefringence. Some structural differences were found when the bone calluses were compared (table 4).

Of the 5 bone samples with an apparently healed callus, only 2 (Sk. 54 and 1,196 - rib sample) presented a truly mature and remodeled microstructure. For exam- 
Fig. 1. a Sternal end of the 9th right rib of an adult female (Sk. 119, 64 years old) who died of bronchopneumonia. $\mathbf{b}$ Detail of the area sampled for analysis showing a slight round elevation (white arrow). c Rib section collected for histological analysis. d Detail of the bone sample after slide preparation, in which is visible an accumulation of bone on the visceral surface.

Fig. 2. Tibiae from an adult male (Sk. 54, 23 years old) who died of pulmonary tuberculosis. a Right tibia showing a consolidated callus on the middle of the diaphysis. Note the presence of slight structural changes of the shaft when compared with the unaffected left tibia. b Detail of the bone callus showing an expanded and smooth surface (medial face). The black asterisk indicates the area sampled for histological analysis. c Magnification of the anterior-lateral portion of the bone callus exhibiting some postmortem detachment of the outer shell of the callus and a small cloaca below the callus. d Bone sample collected for histological analysis, before (left) and after slide preparation (right).
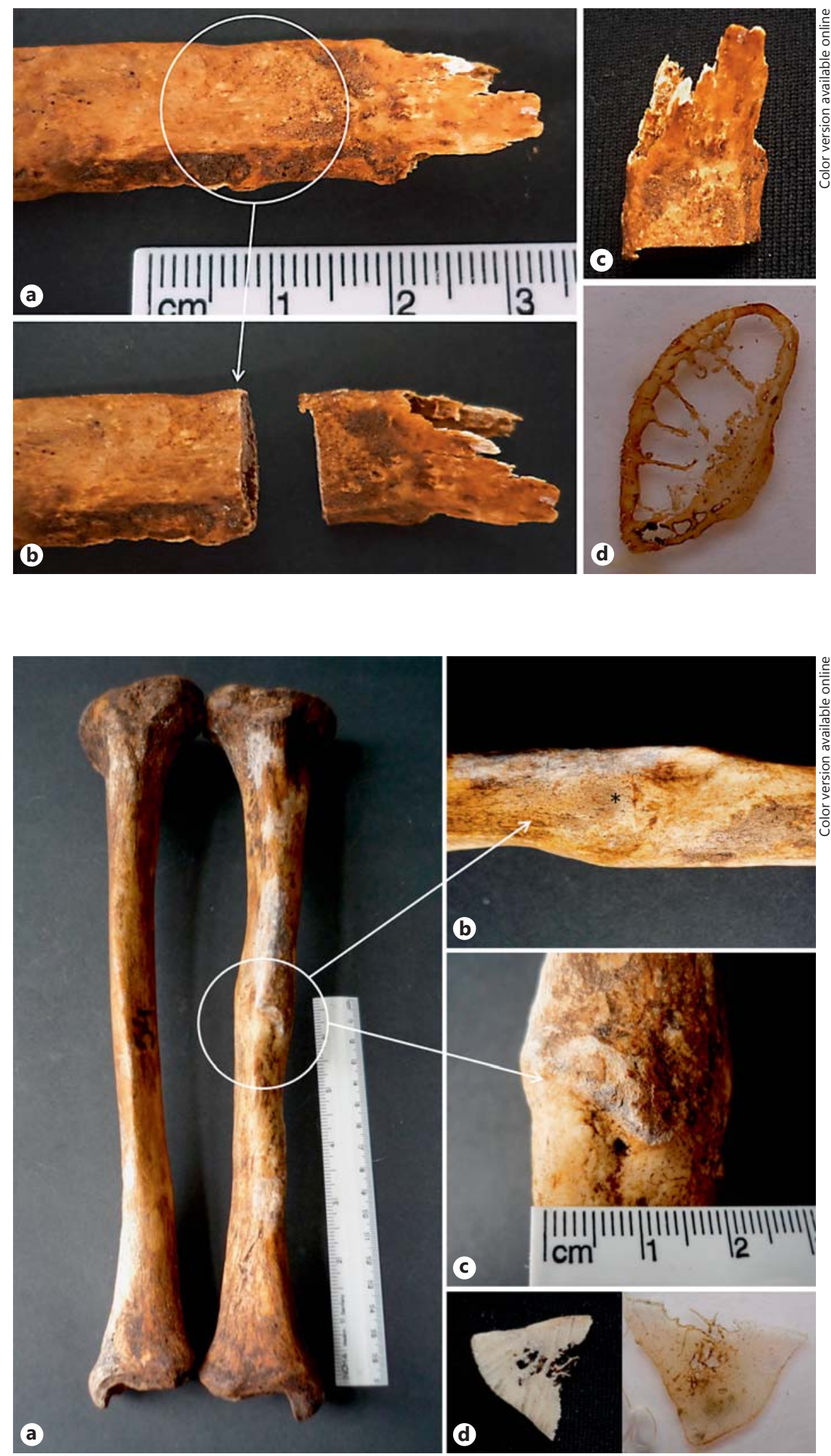
Fig. 3. a Right fibula of an adult male (Sk. 198, 68 years old) who died of urinary sepsis. $\mathbf{b}$ Detail of the bone callus exhibiting a consolidated but irregular morphology. Note the overlapping of the fractured ends. c Magnification of the sample collected for histological analysis, before (left) and after slide preparation (right).
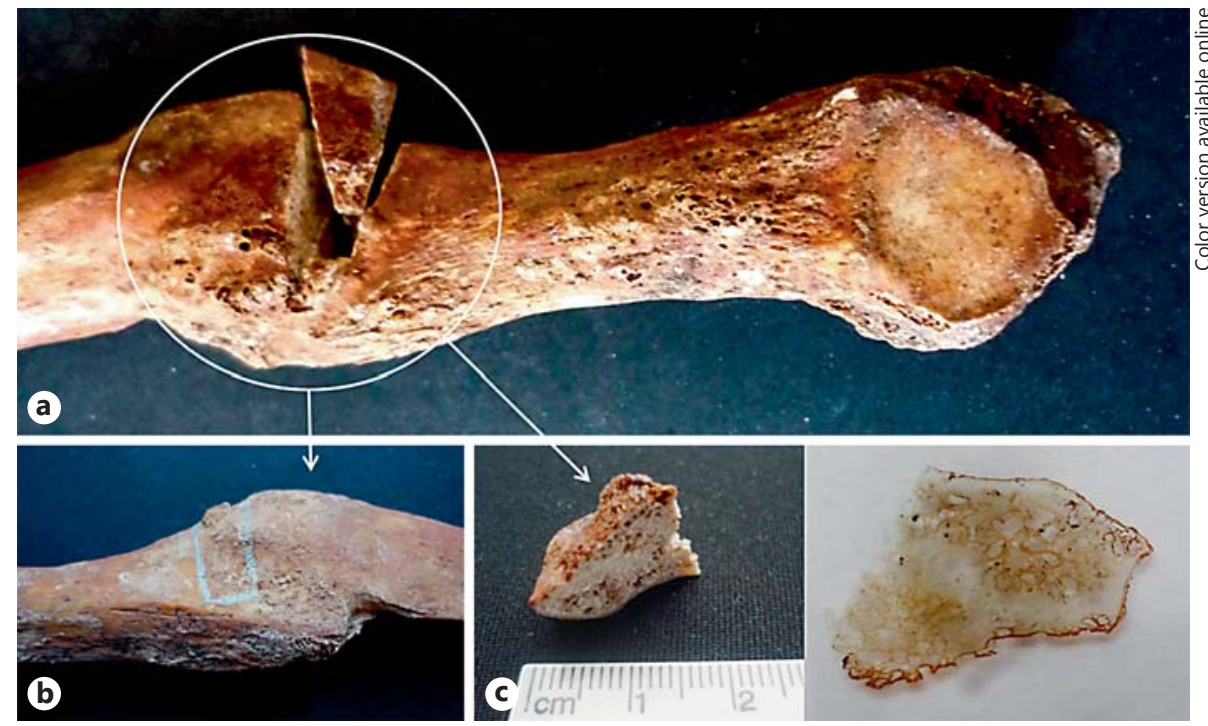
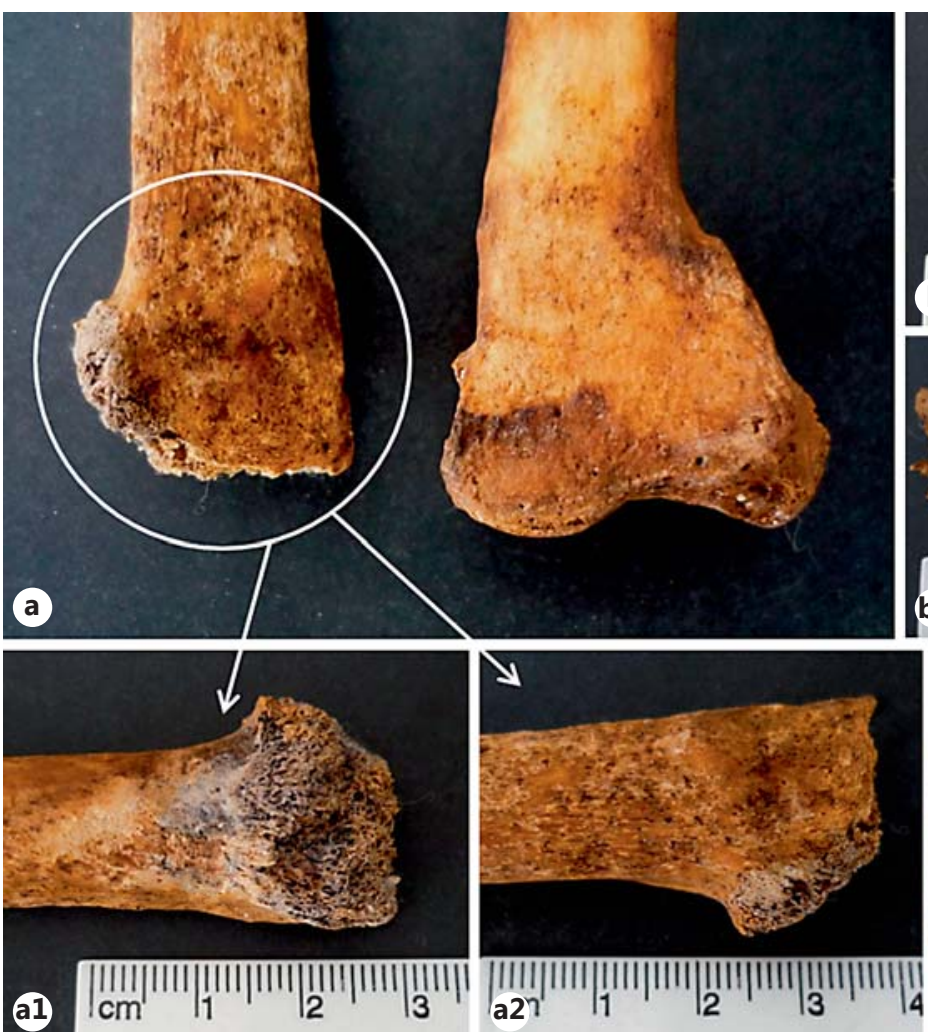

Fig. 4. a Radii from Sk. 1,196, a 75-year-old female who died of arteriosclerosis showing trauma evidence compatible with a Colles fracture. a1 Detail of the bone callus of the right radius exhibiting an abnormal elevation. Note the severe postmortem damage (dorsal view). a2 Anterior view of the affected radius. a3 Magnification of the bone sample collected for histological analysis, before (left)
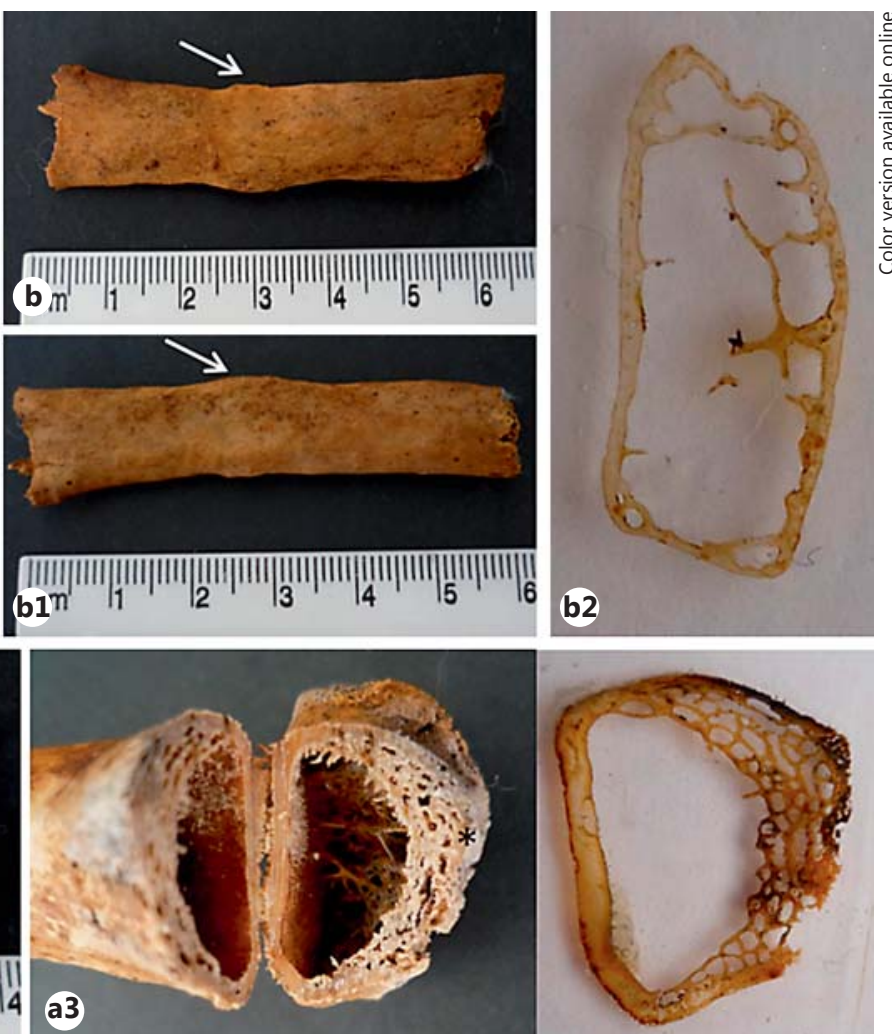

and after (right) slide preparation. The black asterisk indicates the surface sampled for histological analysis. $\mathbf{b}$ Right rib from the same individual with a consolidated callus (white arrow). b1 Visceral surface of the above-mentioned sample highlighting the smooth surface of the callus (white arrow). b2 Detail of the sample collected after slide preparation. 

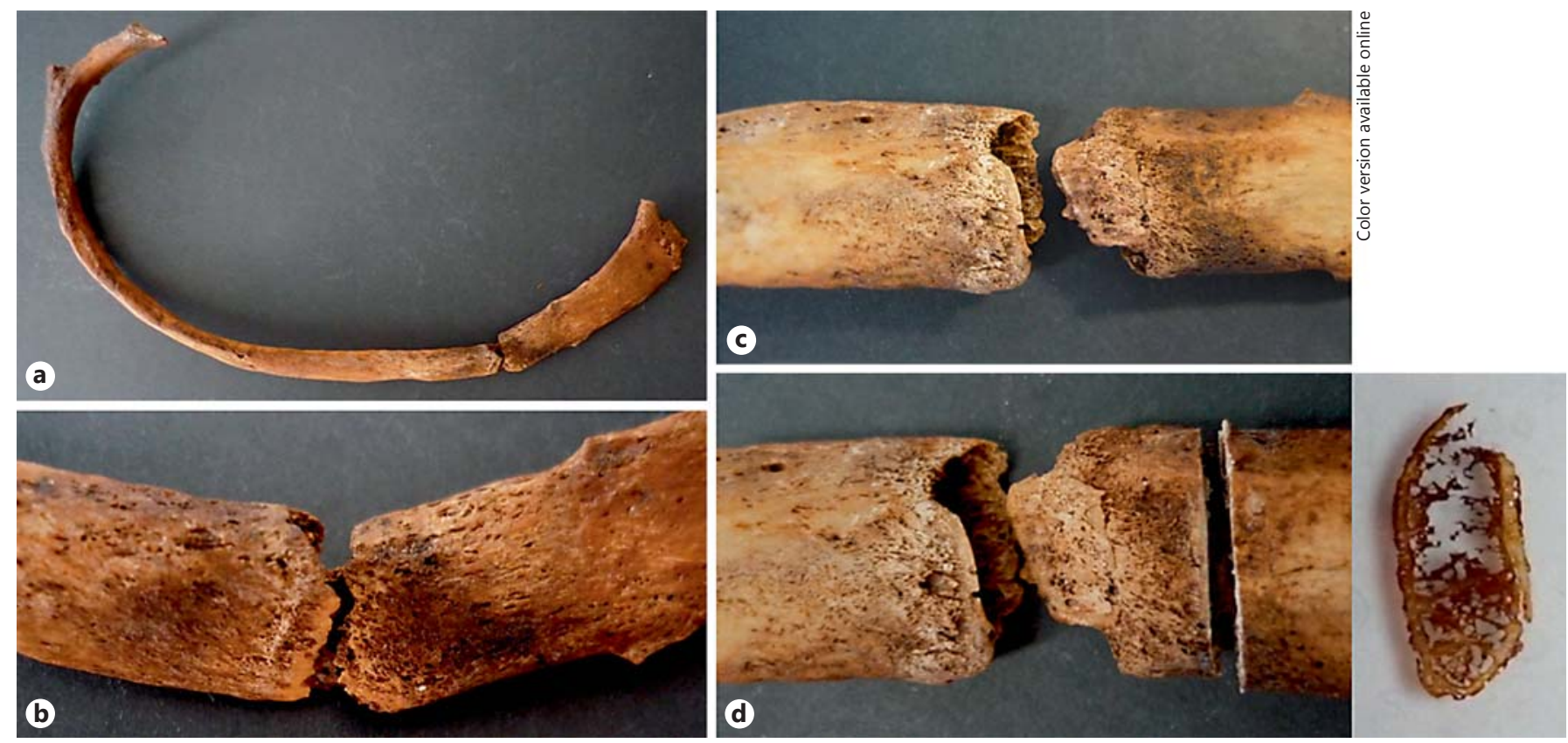

Fig. 5. a The 4 th right rib of the adult male (Sk. 1,138, 86 years old) who died of bronchopneumonia, revealing a complete, unconsolidated fracture in the sternal portion. $\mathbf{b}$ Magnification of the fractured ends showing a sharp morphology and the presence of a rim of newly built bone (dorsal view). c Visceral surface of the rib showing the fractured edges. $\mathbf{d}$ Detail of the previous image showing the new bone foci on the sample (left) and the slide prepared for histological analysis (right). ple, in the lateral portion of the Sk. 54 right tibia callus, a haphazard arrangement of Haversian systems, interstitial lamellae, and enlarged osteon canals crisscrossed by Volkmann's canals was observed. Discontinuous rows of intracortical lamellae, which resemble 'Grenzstreifen' [35-37] were seen separating the inner cortical bone from the secondary compact bone. At some points, erratic resorption lacunae, or sinuous lacunae [37], parallel to the intracortical lamellae were also noticed. In the medial portion of the bone callus, a profusion of randomly organized lamellae in different stages of maturation was observed. In this area, a more chaotic structure formed by osteons, Howship's lacunae and remnants of densely packed lamellae were seen. The periosteal microarchitecture ranged from a thin rim of bone to a denser and/or ruffled surface showing, at some points, irregular resorption spaces (fig. 6a-e).

A remodeled callus microstructure characterized by well-defined osteons and interstitial lamellae was also identified in the right rib sample retrieved from Sk. 1,196. In this sample, multiple bays of bone resorption were observed in the endosteal and periosteal surfaces. At some points, larger areas of bone resorption enclosed by thin layers of bone lamellae were seen, in addition to en- larged Haversian canals and numerous osteocyte lacunae (fig. 7a-d). In contrast with the above-mentioned case, the sample retrieved from the right radius of the same Sk. 1,196 individual showed a more immature microstructure. For example, an intricate network of trabeculae, some of them with signs of bone resorption, was observed in the posterior side of the bone callus. The typical structure of a mature cortical tissue was recorded as absent from the core of the bone callus, as well as from the opposite anterior surface. That is, no clearly defined osteons, interstitial lamellae, and Haversian canals were observed. Instead, the anterior portion appeared to be formed by horizons of lamellar bone pinpointed by a high density of osteocyte lacunae, which suggests distinct levels of bone deposition. Irregular lines running alongside the bone lamellae were also seen. Finally, a pattern of disorganized lamellae and immature bone populated by osteocyte lacunae and separated by irregular areas of bone resorption and discrete Haversian canals was seen in the interface between the anterior and the posterior surfaces of the bone callus (fig. 8a-e1). The most striking example of an immature callus microstructure came from the Sk. 198 sample. In spite of the healed macroscopic appearance, the histological study revealed a cortical tissue formed by an 
Table 4. Evaluation of the histological features of the bone callus by individual, sample, healing stage, and type of trauma diagnosis

\begin{tabular}{|c|c|c|c|c|}
\hline \multirow[t]{2}{*}{54} & \multirow[t]{2}{*}{$\begin{array}{l}\text { Right } \\
\text { tibia }\end{array}$} & $\begin{array}{l}\text { Lateral portion of the bone callus } \\
\text { Cortical bone formed by multiple rows of osteons with different sizes and } \\
\text { shapes embedded in interstitial lamellae; } \\
\text { Presence of some enlarged Haversian canals, interstitial lamellae and } \\
\text { Volkmann's canals crossing multiple Haversian systems; } \\
\text { Presence of a thin rim of periosteal circumferential lamellae enclosing the } \\
\text { cortical tissue }\end{array}$ & Fracture & Healed \\
\hline & & $\begin{array}{l}\text { Medial portion of the bone callus } \\
\text { Thicker layer of periosteal bone and a more uneven organization of the } \\
\text { cortical tissue; } \\
\text { Evidence of osteoclastic activity at the periosteal level; } \\
\text { Presence of dense sheets of lamellae occupying an intracortical position } \\
\text { ('Grenzstreifen') and of sinuous lacunae }\end{array}$ & & \\
\hline & $\begin{array}{l}\text { 9th right } \\
\text { rib }\end{array}$ & $\begin{array}{l}\text { Cortical bone } \\
\text { Distinct levels of organization: the inner cortex is composed of multiple rows } \\
\text { of osteons and interstitial lamellae, whereas the outer cortex is formed by } \\
\text { individualized sheets of lamellae randomly interconnected by Haversian systems; } \\
\text { the inner cortex is populated by a large number of osteocyte lacunae }\end{array}$ & & \\
\hline 1,138 & $\begin{array}{l}\text { 4th right } \\
\text { rib }\end{array}$ & $\begin{array}{l}\text { Pleural surface } \\
\text { Presence of an arc-like rim of newly built bone separated from the underlying } \\
\text { cortex by resorption spaces; } \\
\text { Presence of enlarged Haversian canals and irregular resorption spaces in the } \\
\text { cortex (beneath the periosteal new bone deposition); } \\
\text { Presence of an intricate network formed by trabeculae and preserved blood } \\
\text { vessels near the endosteal surface }\end{array}$ & Fracture & $\begin{array}{l}\text { Healing, } \\
\text { reparative } \\
\text { stage }\end{array}$ \\
\hline 1,196 & $\begin{array}{l}\text { Right } \\
\text { rib }\end{array}$ & $\begin{array}{l}\text { Cortical bone formed by a unique row of osteons and interstitial lamellae; } \\
\text { Presence of enlarged Haversian canals and multiple foci of bone resorption } \\
\text { (>endosteal surface) }\end{array}$ & Fracture & Healed \\
\hline
\end{tabular}


Table 4 (continued)

\begin{tabular}{|c|c|c|c|c|}
\hline Sk. & $\begin{array}{l}\text { Bone } \\
\text { element }\end{array}$ & Histological description of the bone callus features & $\begin{array}{l}\text { Type of trauma } \\
\text { diagnosis }\end{array}$ & $\begin{array}{l}\text { Healing } \\
\text { stage }\end{array}$ \\
\hline \multirow[t]{2}{*}{1,196} & \multirow[t]{2}{*}{$\begin{array}{l}\text { Right } \\
\text { radius }\end{array}$} & $\begin{array}{l}\text { Anterior portion of the bone callus } \\
\text { Composed of multiple horizons of lamellae: the outermost layers presented a } \\
\text { compact appearance whereas those close to the endosteal surface exhibited a } \\
\text { more disorganized structure; } \\
\text { Presence of } 2 \text { incompletely healed microfractures running parallel to the } \\
\text { periosteal-endosteal surface; } \\
\text { No Haversian systems were observed }\end{array}$ & Fracture & $\begin{array}{l}\text { Healing, } \\
\text { remodeling } \\
\text { stage }\end{array}$ \\
\hline & & $\begin{array}{l}\text { Posterior portion of the bone callus } \\
\text { Formed by a bulky network of trabeculae characterized by a haphazard } \\
\text { arrangement of their mineralized collagen fibers, as well as by the presence of } \\
\text { numerous osteocyte lacunae; } \\
\text { Presence of multiple foci of bone resorption }\end{array}$ & & \\
\hline
\end{tabular}

intricate system of lamellae, comparable to trabeculae, in which multiple branches and islands of well-preserved lamellae connecting partially digested osteons were observed. A combination of mature lamellae with more immature bone populated by multiple osteocyte lacunae and large resorption spaces was also noticed. At the periosteal level, a rim of lamellae in distinct stages of maturation was seen bordering the outer surface of the bone (fig. 9a-d).

A complete unhealed fracture was observed on the 4th right rib of the adult male Sk. 1,138. In this particular case, the most revealing histological feature observed was the presence of an arc-like structure of new bone connected with the underlying cortex by bone pedestals. Intact endosteal and periosteal circumferential lamellae were also visible, as were remnants of blood vessels. In fact, a network formed by rib trabeculae and preserved blood vessels was observed on the endosteal surface. Enlarged Haversian canals and irregular resorption spaces were visible at the cortical level (fig. 10a-c1).

With regard to the Sk. 119 rib callus, no evidence of a cortical bone break was observed. Actually, the cortex exhibited a mature structure composed of numerous rows of osteons and interstitial lamellae. In the upper and lower edges of the pleural surface, a clear separation between the cortical bone and the patches of periosteal new bone was noticed. This level of microstructural organization was clearly distinguishable from the mesh-like pattern of interconnected lamellae and amorphous new bone for-

Paleohistology and the Biology of Bone Healing mation noticed on the central portion of the pleural surface. Moreover, an accumulation of new bone in distinct stages of maturation was also observed. For instance, the deepest layers were formed by densely packed lamellae with small, elongated and erratic osteocyte lacunae, whereas the outermost ones were composed of a random structure with an immature appearance and were densely populated by circular osteocyte lacunae (fig. 11a-c1).

\section{Discussion}

Apart from the macroscopic and radiological scrutiny, few paleopathological studies have applied histological techniques to characterize different types of injury lesions [38-45] or to understand the timings of posttraumatic healing [46-49]. The results of this exploratory investigation showed that gross inspection may be insufficient to describe and characterize trauma lesions or to understand the biology of disease.

Despite the morphology of the outer shell of the Sk. 119 rib callus, which resembles a consolidated fracture, the histological study showed an unremodeled architecture compatible with a subperiosteal hematoma eventually caused by periosteum detachment, bleeding, and new bone formation through activation of the osteogenesis process. Nevertheless, a case of an incomplete microfracture cannot be completely excluded from the present diagnosis. 

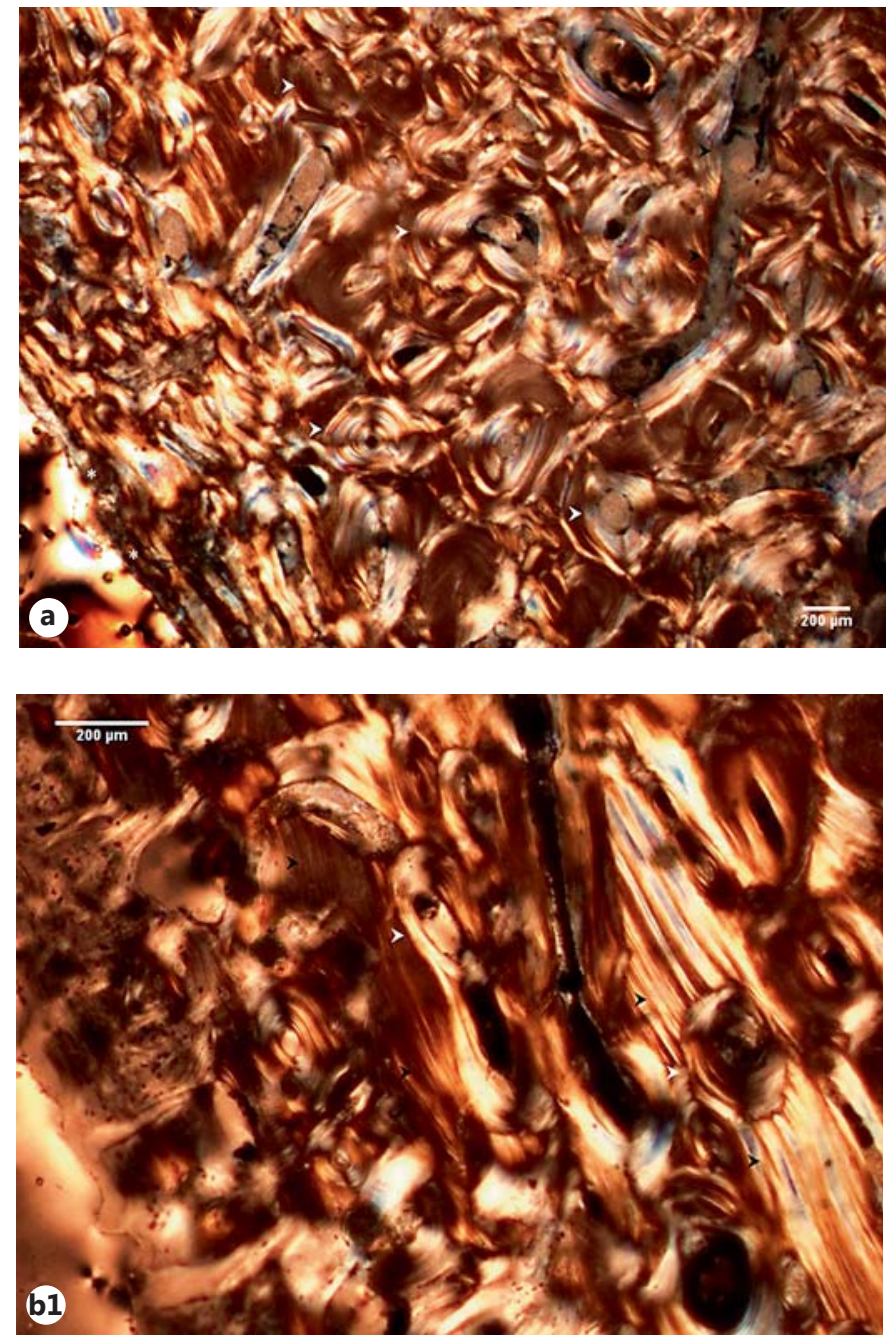

Fig. 6. a Microscopic view of the Sk. 54 right tibia sample showing the cortical tissue formed by osteons (white arrowheads) intersected, at some points by Volkmann's canals (black arrowheads). The periosteal surface was composed of a thin rim of bone (white asterisks). b Segment formed by osteons, intracortical lamellae (circle 1), and resorption spaces (circle 2). b1 Detail of the intracortical lamellae (or 'Grenzstreifen'; black arrowheads) separating rows of osteons (white arrowheads). b2 Another magnification showing some resorption lacunae (or sinuous lacunae; white asterisk) in the intracortical lamellae (black arrowheads) and at the
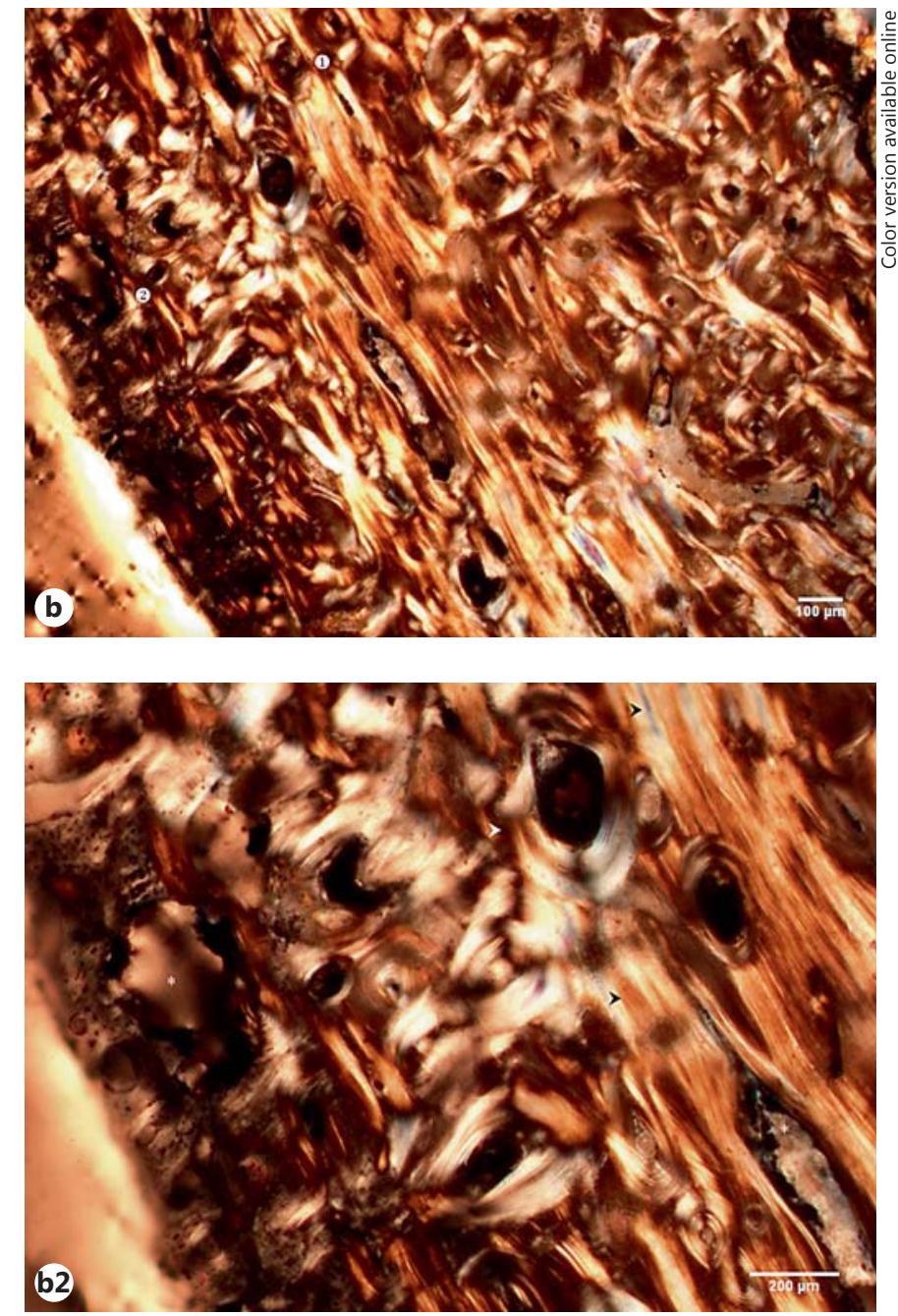

periosteal surface (white asterisk). Note the presence of osteons with enlarged Haversian canal (white arrowhead). c Segment showing a haphazard cortical microstructure formed by osteons (white arrowheads), interstitial lamellae (white asterisks), and compact intracortical lamellae (black arrowheads). d Thick layer of dense bone at the periosteal surface (black asterisks) connecting the cortical tissue formed by different sized osteons (white arrowheads). e Another segment revealing erratic osteons (white arrowheads) surrounded by elongated intracortical lamellae (black arrowheads). Polarized light. Magnification $\times 40 ; \times 100$.

(For figure 6c-e see next page.)

The microstructure of hematoma is variable, ranging from thin layers that resemble a slip-like cover to relatively short, bulky bone trabeculae with extensive bridging, arclike formation, and/or multiple layers [35-37]. In the case under discussion, the presence of tissues in distinct stages of maturation: immature and more disorganized bone/ isodiametric osteocyte lacunae (outer layers) and lamellar bone/flattened osteocyte lacunae (deepest layers) seem to indicate that the bone lesion was undergoing remodeling at the time of death. Little can be said about the elapsed time after hematoma formation; nevertheless, and during fracture repair, the remodeling of woven bone into longitudinally oriented lamellar bone is observed to occur 1421 days after injury [48]. Independently of the diagnosis, the presence of 9 rib calluses ( $n=6$, right ribs; $n=3$, left ribs; table 2) seems to indicate that this female was exposed 

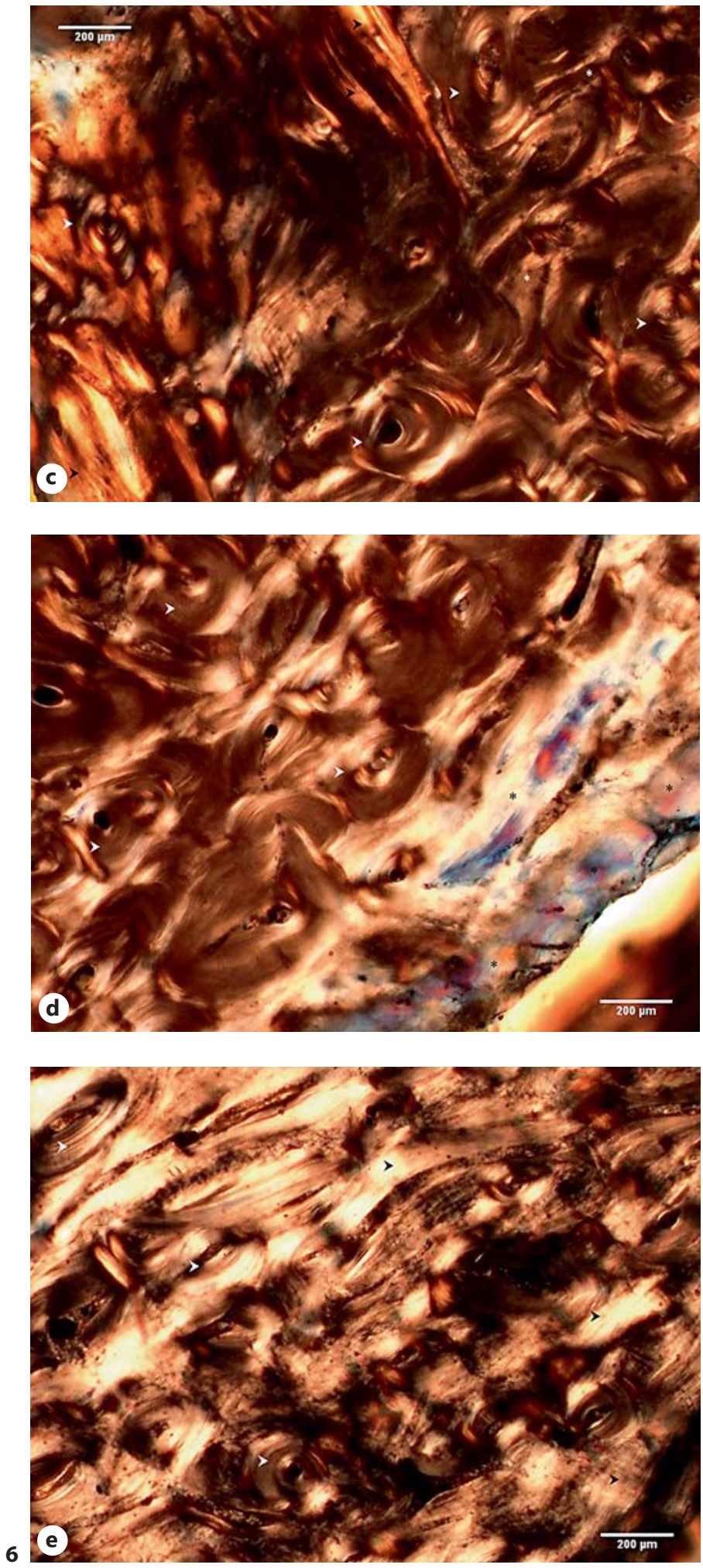

Paleohistology and the Biology of Bone Healing to chest trauma that caused a minor tissue disruption in the 9 th right rib.

With regard to the Sk. 198 right fibula callus, the meshlike pattern observed seems to mirror the last phases of the reparative stage. The remodeling phase is the longest (it may require 6-9 years in adults) and aims to reestablish the skeletal integrity $[50,51]$. The reparative phase is characterized by the development of an organized fibrous mass [52] in a process that recapitulates the embryonic intramembranous and endochondral ossifications [5355]. This soft or fibrous callus will bond the broken ends [24] and guarantee the mechanical stability of the injured area [56]. Other local changes include mineralization [50], degradation of the nonmineralized matrix, and the formation of new trabeculae, which compounds the primary bony callus [24]. In the study of bone callus morphogenesis, Gerstenfeld et al. [57] showed that during the endochondral process of fracture healing, the cortex and cartilage undergo resorption, being replaced by an inner supporting network of trabeculae that will stabilize the fracture. Ayoub et al. [58] also observed a characteristic histological picture characterized by islands of newly built bone surrounded by cartilage and interspersed, at some points, by lamellar bone. The reparative stage may last several weeks. In some cases, the bony callus may originate as early as the first week after injury [59]. Analyzing the morphology of mineralized bone calluses, Liu et al. [60] noticed that a microstructure composed of poorly organized tissue (woven bone) and well-aligned lamellae develops during the 2-9 weeks of healing.

In contrast with the aforementioned case, the histomorphology of the Sk. 54 bone callus is compatible with a mature and remodeled fracture. The presence of a cloaca and the observation of small patches of intracortical lamellae or 'Grenzstreifen' confirm that this individual had developed a posttraumatic osteomyelitis. Albeit more common in specific infections characterized by slowly growing new bone formation (treponematoses) [35-37, 61], 'Grenzstreifen' may also occur in cases of nonspecific osteomyelitis [37]. In the case under discussion, the 'Grenzstreifen' separates the original cortical bone affected by trauma from a secondary inflammatory process imposed by osteomyelitis.

Like osteomyelitis, pseudarthrosis is another severe fracture complication. It develops when the broken extremities fail to form a bony union, which may happen, for instance, by lack of immobilization [52, 62]. The continuing mobility of the affected area may culminate in the formation of a pseudojoint associated with extensive callus formation $[24,62]$. In cases of fracture nonunion, pseud-

Pathobiology 2016;83:177-195 187 

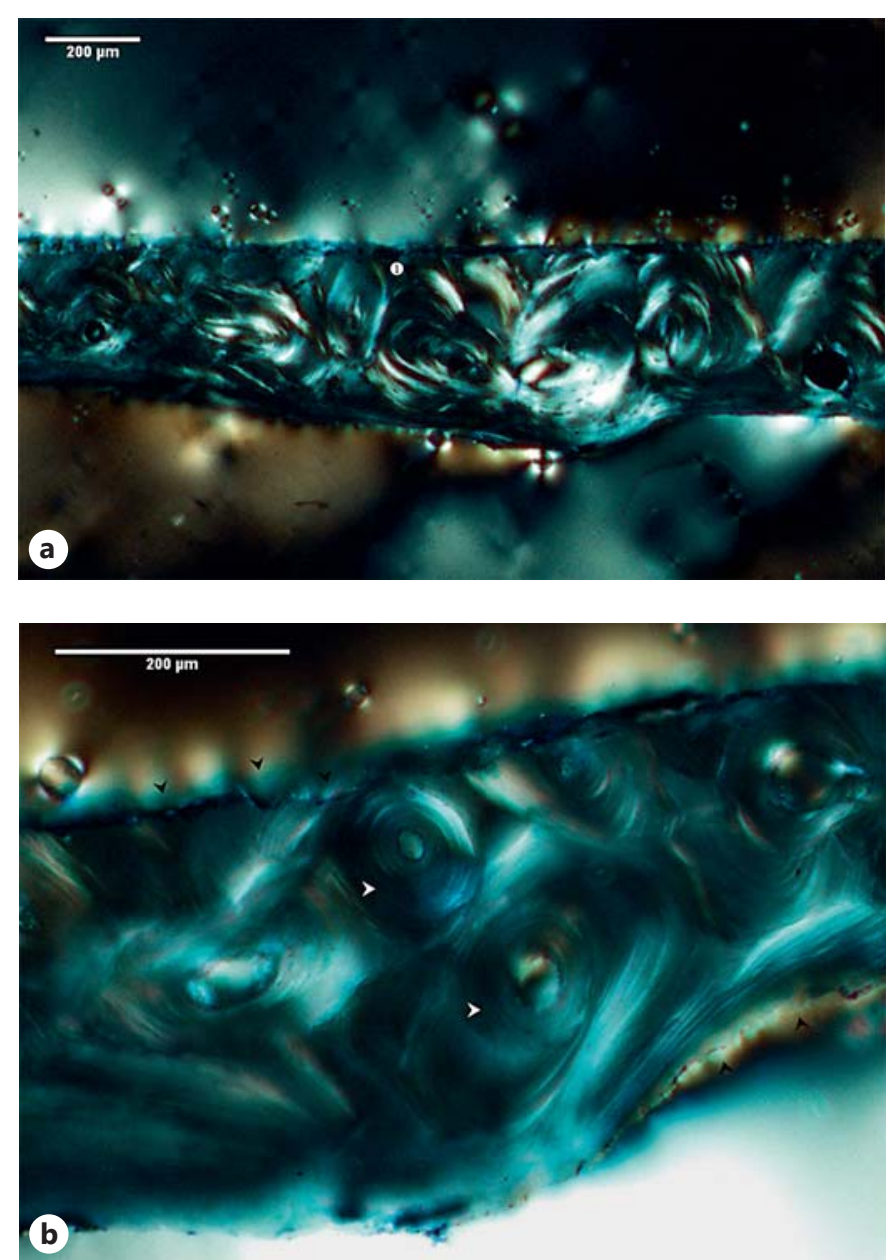

Fig. 7. a Micrograph of the right rib sample of the SK. 1,196 individual exhibiting the cortical tissue (circle 1). a1 Detail of the previous figure showing a thin row of osteons (white arrowheads) and interstitial lamellae (white asterisks). b Another segment revealing bays of bone resorption in the endosteal and periosteal surfaces (black arrowheads) and some intact cortical osteons (white arrowheads). c Segment showing a larger area of cortical (white asterisk) and endosteal (black arrowheads) bone resorption. d Illustration of a segment under plane light exhibiting a row of osteons (white arrowheads) with enlarged Haversian canals and numerous osteocyte lacunae. Polarized light. Magnification $\times 40 ; \times 100$.
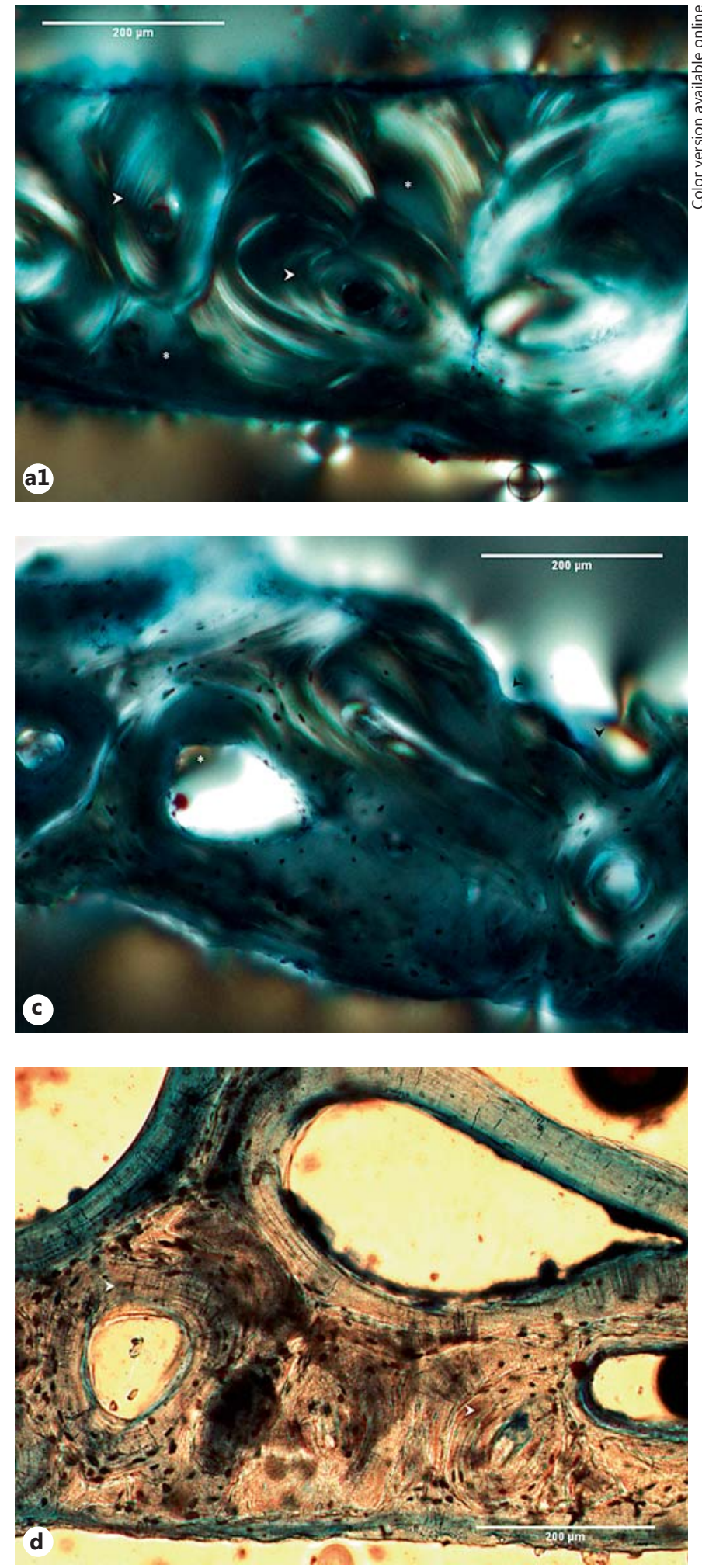

Assis/Keenleyside 

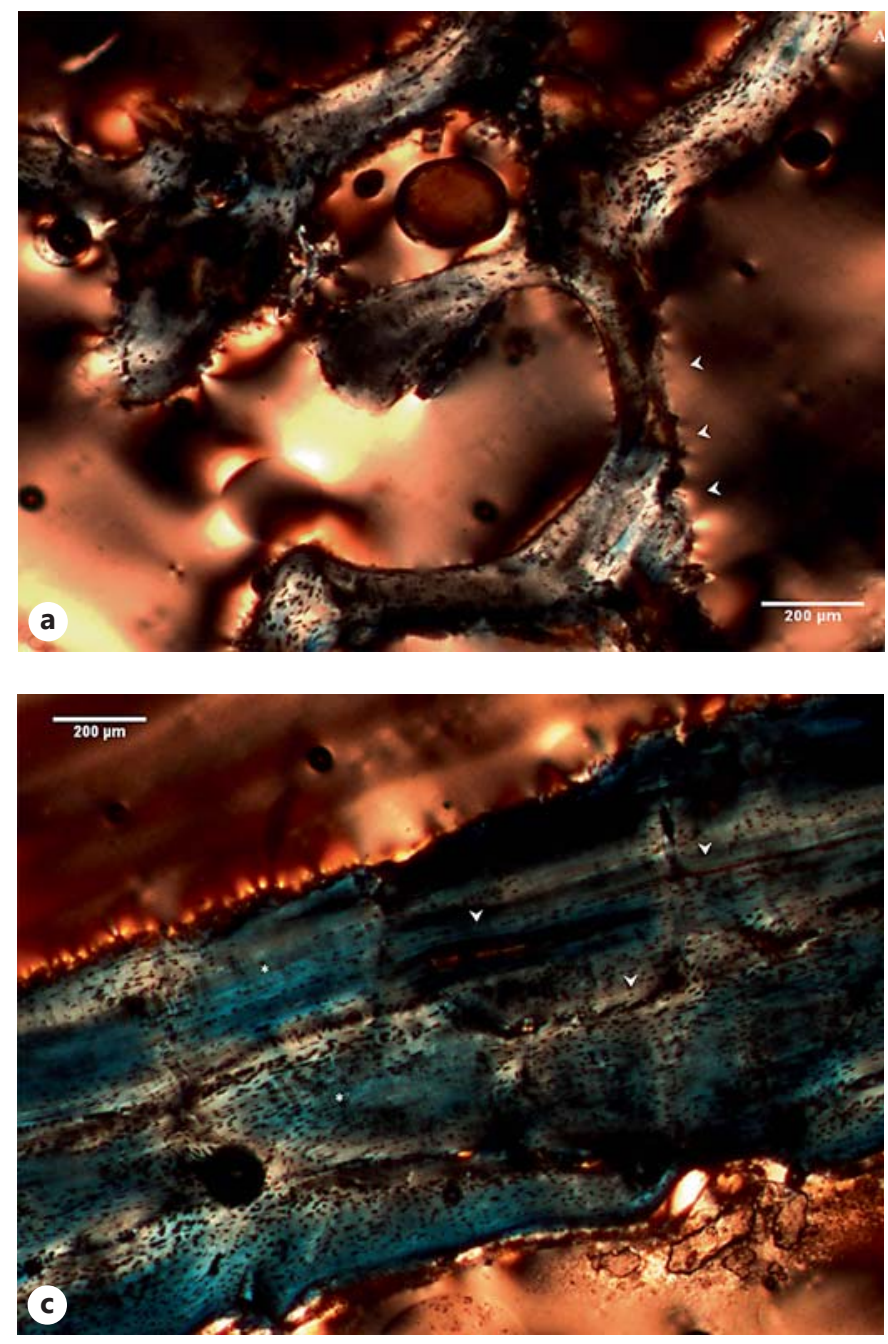

Fig. 8. a Micrograph of the posterior portion of the SK. 1,196 right radius bone callus showing scattered trabeculae erased by foci of bone resorption (white arrowheads). b Illustration of the anterior portion of the callus revealing lamellar bone apposition with variable density and organization (white asterisks). c Another view revealing distinct layers of lamellae (white asterisks) separated by longitudinal lines (white arrowheads). d Area showing cortical lamellae mixed with more immature and disorganized forms of bone

arthrosis may mimic the healing process, leading to misdiagnosis [63]. With regard to the unhealed Sk. 1,138 rib fracture, the absence of a 'false joint' makes a diagnosis of pseudarthrosis improbable. Accordingly, the histological features observed (periosteal osteogenesis distant from the lesion edges and separable from the cortex and cortical osteoporosis) are more compatible with the reparative stage of the healing process, pointing to a possible posttraumatic survival interval of 7-14 days [47]. As mentioned previously, the Sk. 1,138 individual exhibited 7 un-

Paleohistology and the Biology of Bone Healing
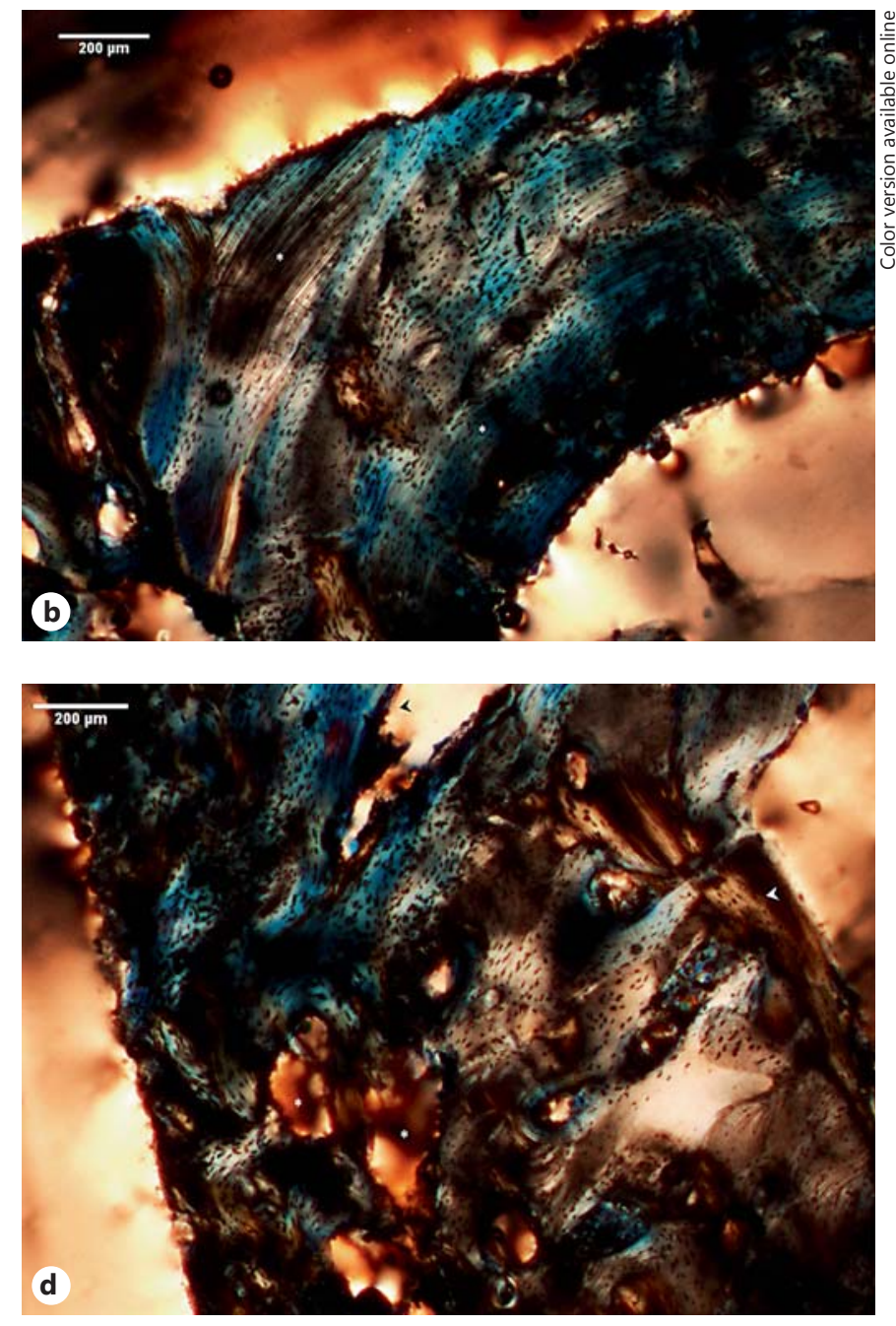

(white and black arrowheads), and spaces of bone resorption (white asterisks) and discrete vascular canals. e Segment exhibiting a haphazard arrangement of bone lamellae in distinct stages of maturation (white arrowheads), as well as enlarged resorption spaces (white asterisks). e1 Detail of the previous figure highlighting the orientation of the mineralized collagen fibers and the numerous osteocyte lacunae. Polarized light. Magnification $\times 40 ; \times 100$.

(For figure 8 e see next page.)

healed fractures (in a total of 15 bone calluses) distributed through 9 ribs. Although acute chest trauma is a possible explanation for the lesions observed, one cannot put aside the eventual contributions of age and associated bone fragilities. In addition to age, numerous factors such as the type, location, and severity of the fracture, the stability of the fractured ends, or the adequacy of the vascular supply may affect the healing process $[24,52]$. Few conclusions can be drawn from the impact of the causes of death of the individuals on the duration of the healing process; never- 

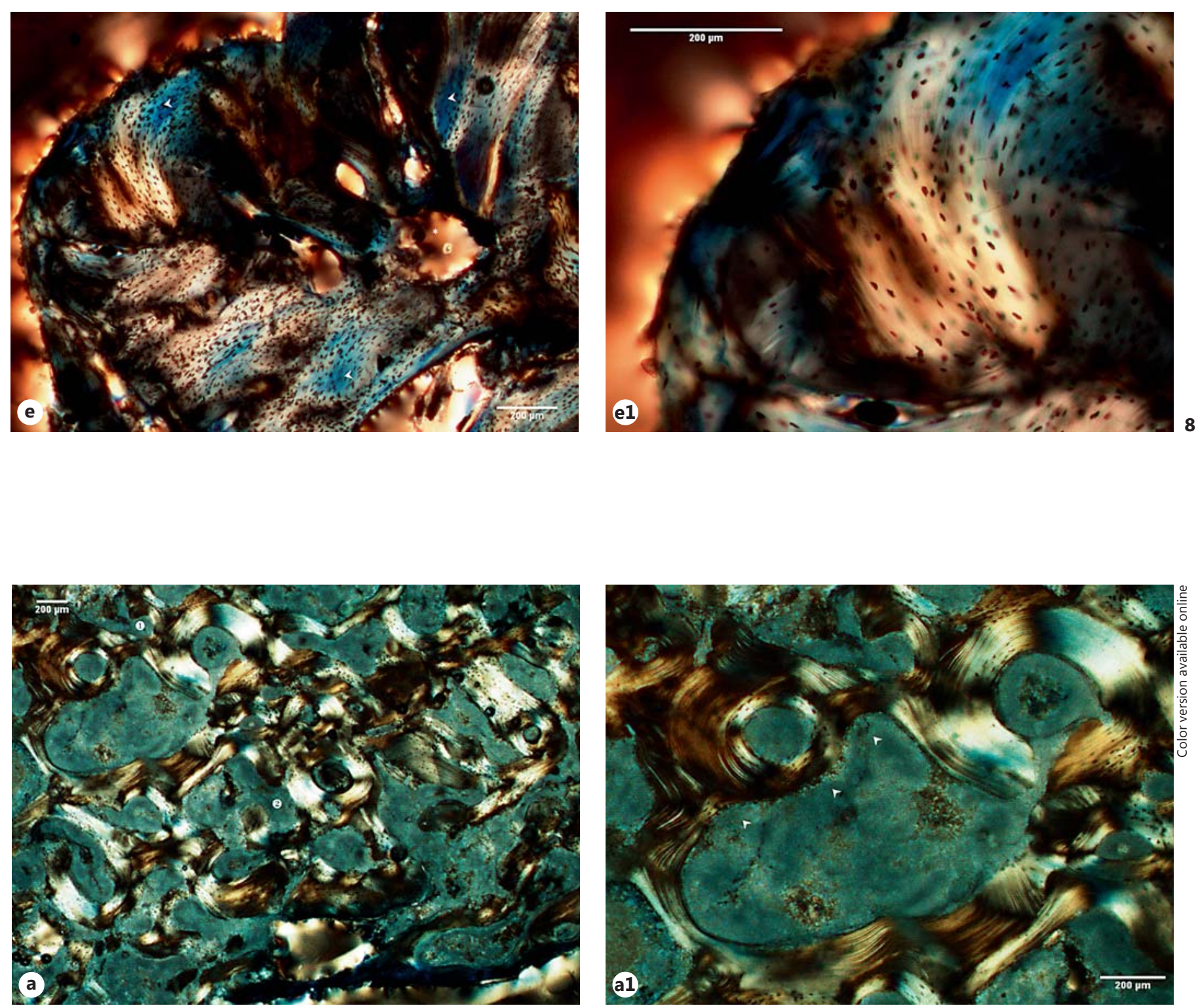

Fig. 9. a Microscopic view of the Sk. 198 right fibula callus showing the cortical tissue formed by a disorganized net of bone lamellae and remnants of ancient Haversian systems (circle 1 and 2). a1, a2 Details of the previous image showing large bays of bone resorption being formed after digestion of previous osteons (white arrowheads). b Another view highlighting numerous areas of bone resorption. b1 Magnification of the previous image revealing the large and irregular areas of bone resorption (white arrowheads). b2 Another magnification showing mature (white arrowheads) and more recently formed lamellae with osteocyte lacunae (black arrowheads). c Bone segment combining densely packed lamellae on the bone surface (black arrowheads) and branches of disorganized lamellae with osteocyte lacunae in the innermost areas of the cortical bone (white star). $\mathbf{d}$ Another view showing the outer surface composed of lamellae with a haphazard arrangement (white star) and pinpointed by numerous osteocyte lacunae. Polarized light. Magnification $\times 40 ; \times 100$.

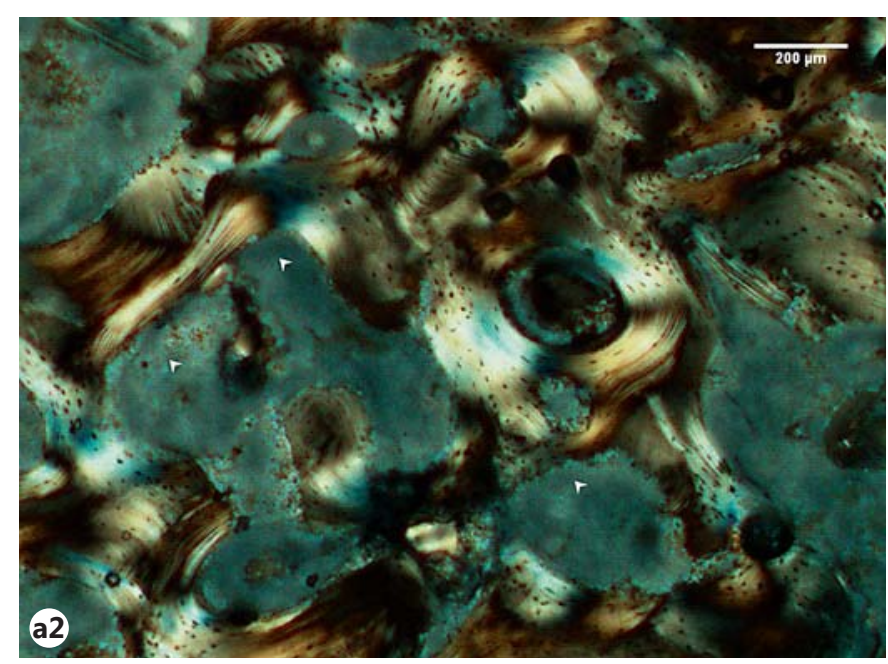

(For figure $9 b-d$ see next page.) 

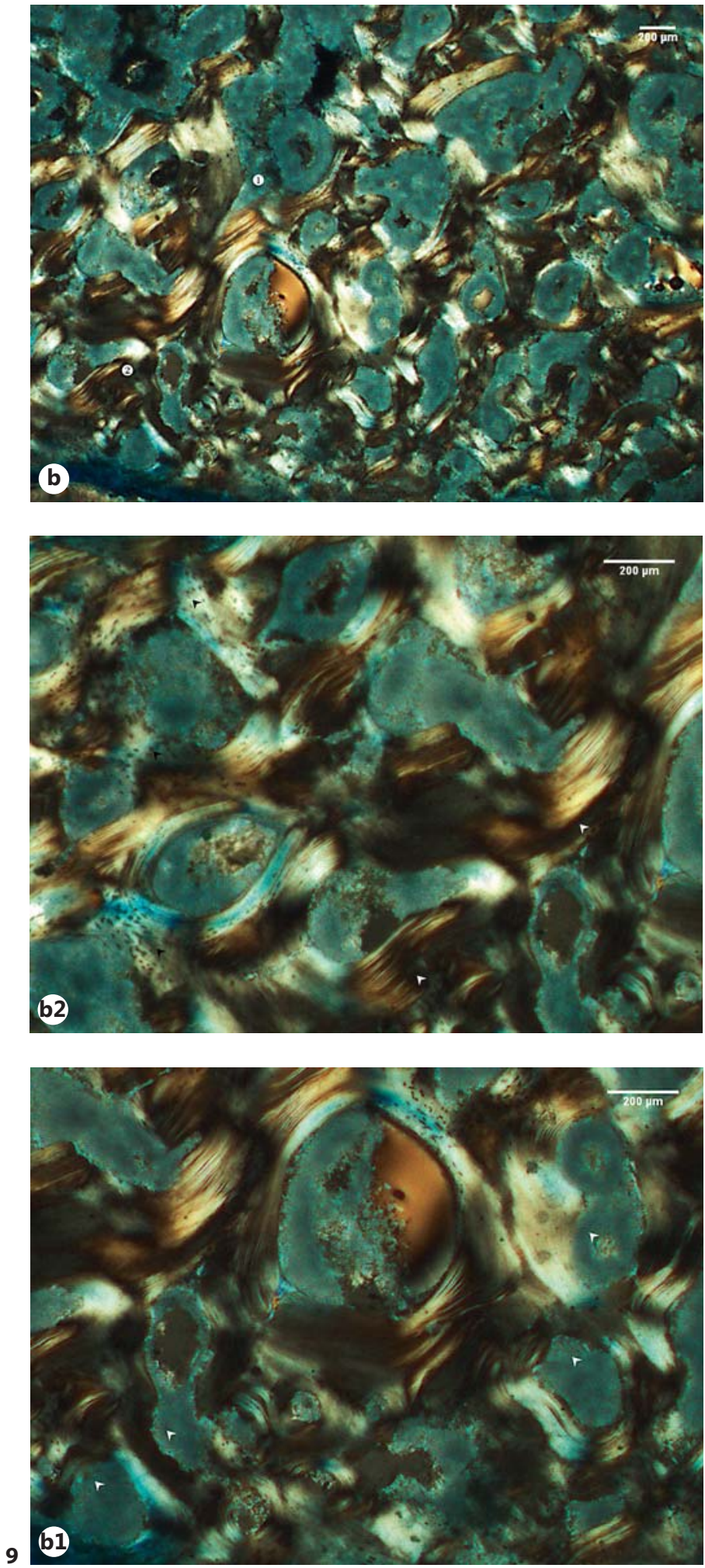

Paleohistology and the Biology of Bone Healing
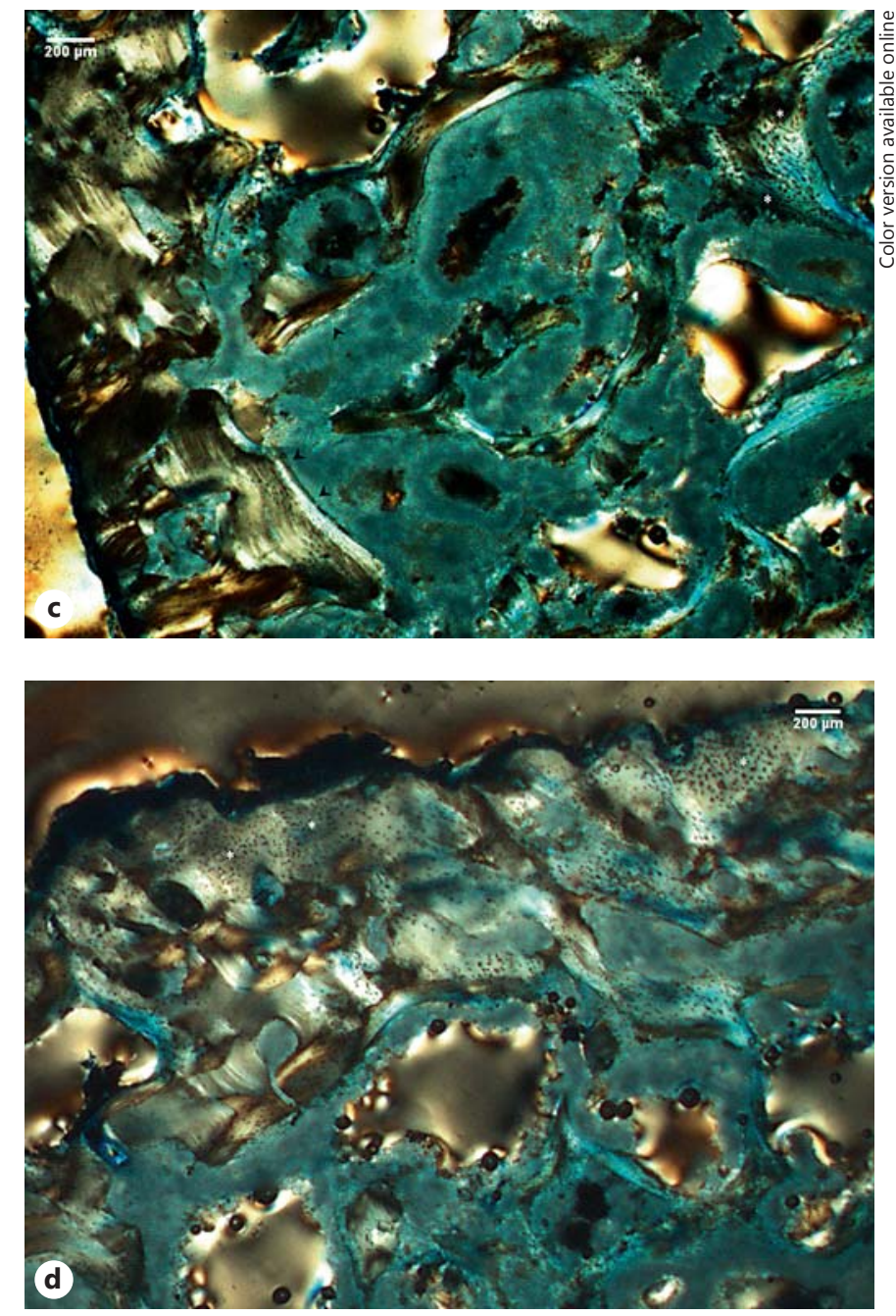

theless, the age, and possibly the health condition, may have played a role in some of the cases described, namely in the healing of the Sk. 1,196 calluses. In the radius, for instance, the presence of a callus with partially digested trabeculae and unremodeled lamellae seems to suggest the existence of an underlying condition. It appeared that the bone was continuously laid down in a lamellar fashion without being converted into secondary Haversian systems. Some metabolic disorders may reduce the bone turnover [64]. When this happens, there is more time for secondary mineralization to proceed; as a consequence, the bone tissue becomes hypermineralized and more brittle, requiring less energy to microdamage [65]. Aging also diminishes the ability of bone to repair, leading to osteopenia and, in severe cases, to osteoporosis [66]. In addition to the presence of fractures (Colles fracture, vertebrae, hip,

Pathobiology 2016;83:177-195 

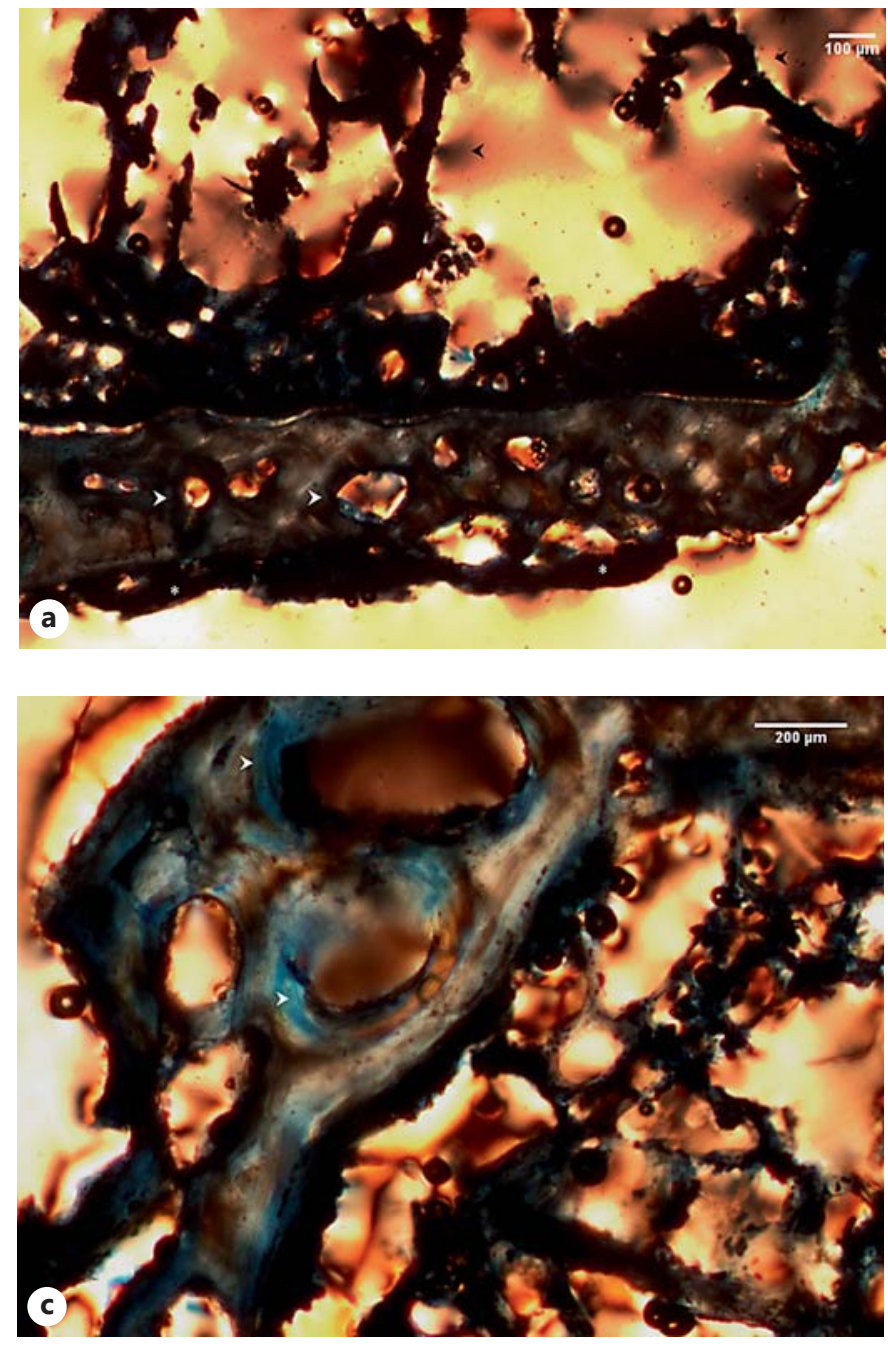

Fig. 10. a Micrograph of the Sk. 1,138 rib cortical tissue presenting mature osteons and enlarged Haversian canals (white arrowheads) and a deposit of new bone with an arc-like microanatomy at periosteal level (white asterisks). Note the presence of rib trabeculae and preserved blood vessels (black arrowheads). b Another view
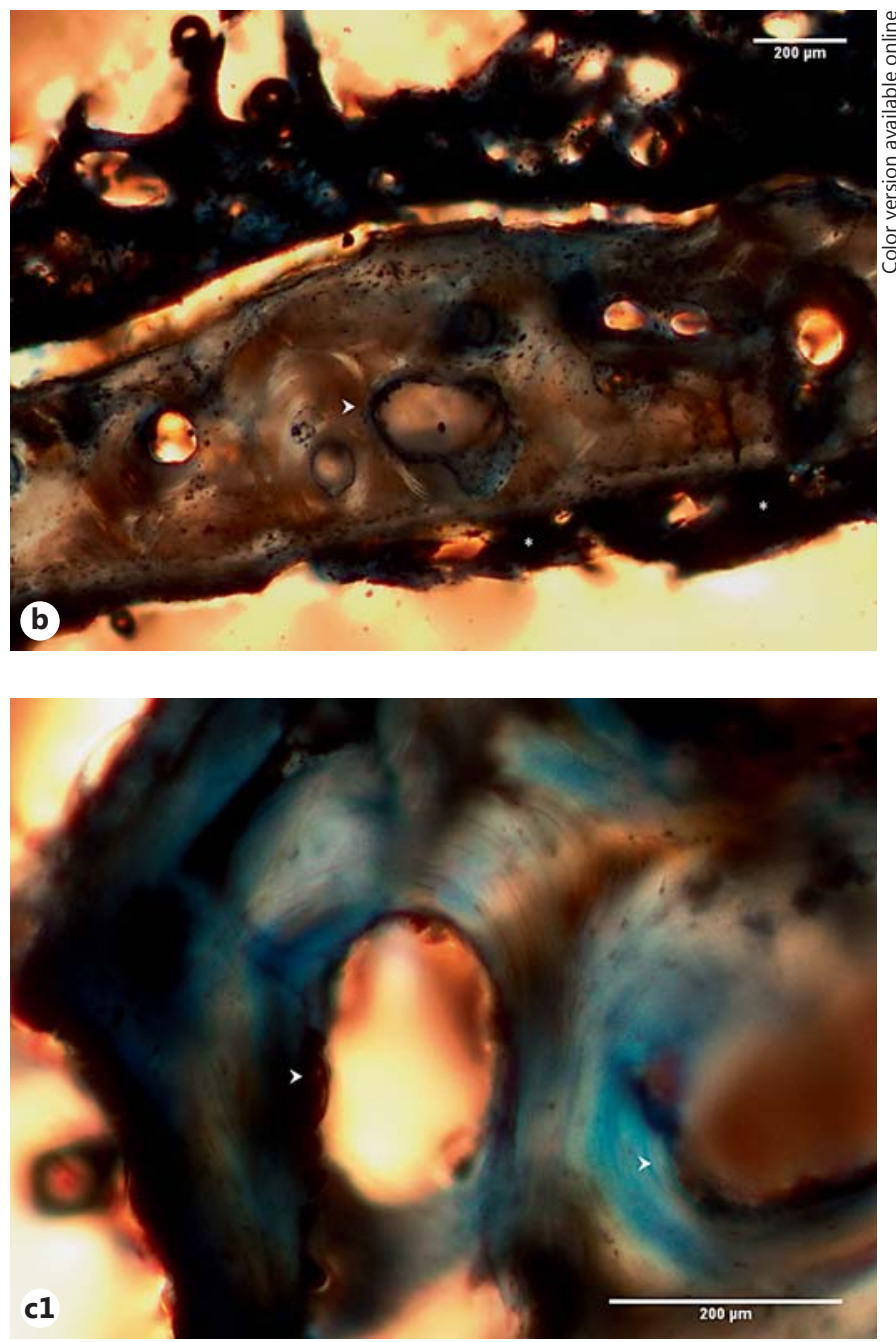

pinpointing a major area of osteonal bone resorption (white arrowheads) and the newly built bone (white asterisks). c, c1 Bone segments showing massive foci of osteon resorption (white arrowheads). Polarized light. Magnification $\times 40 ; \times 100$.

\section{Conclusion}

increased resorption and/or marked coalescence of resorption spaces, mineralization defects, and microcracks [66 and authors herein]. These changes were noticed in the radius and in the rib samples. In spite of being difficult to ascertain whether the fractures were predisposed by a metabolic disorder, it may be hypothesized that it was affecting the healing process. Through histological analysis, it was also possible to verify that Sk. 1,196 suffered multiple traumatic episodes; an early one was completely healed at the time of death (rib fracture), and the other was healing when the individual died (radius fracture).
In spite of the small number of samples, this study showed that histology is important for several reasons. Firstly, it is essential to accurately identify the stage of fracture healing, information that cannot be retrieved entirely from gross inspection and radiological analysis. In fact, some studies consider that the timing of fractures determined radiographically, especially in children, may be uncertain $[67,68]$. The determination of the posttraumatic survival interval is important not only to understand how past populations coped with injury but also because it as- 

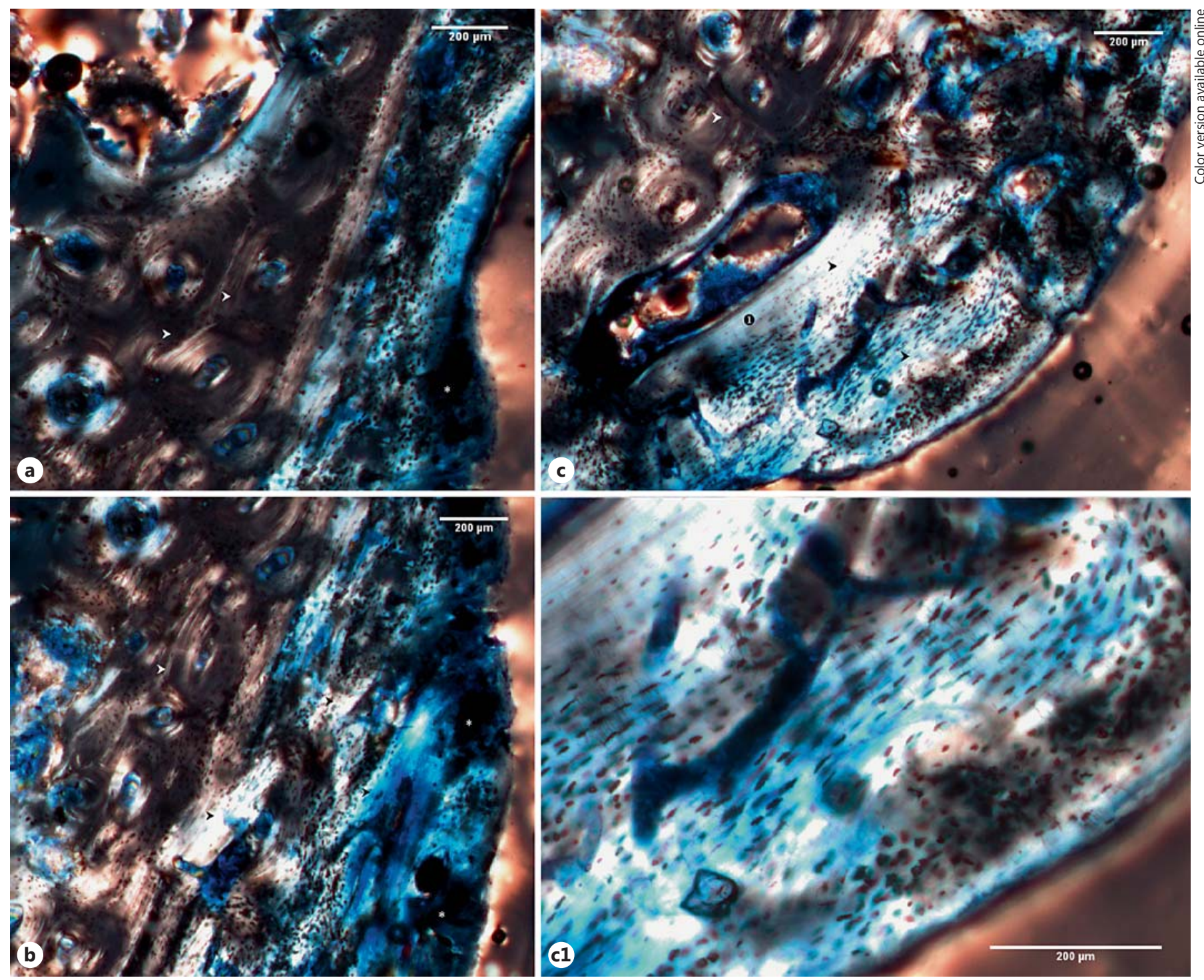

Fig. 11. a Micrograph of the Sk. 119 right rib showing the cortical tissue composed of mature osteons (white arrowheads) and interstitial lamellae. A clear separation between the periosteal circumferential lamellae and a more disorganized periosteal new bone formation (white asterisk) is visible. $\mathbf{b}$ Segment exhibiting several rows of osteons (white arrowhead) intersected by sheets of lamellar bone with variable density (black arrowheads). Note the presence of a lumpy deposit of periosteal new bone (white asterisks). c Perios- teal new bone formation exhibiting several degrees of bone organization (black arrowheads; circle 1). Multiple osteons are visible at the cortical level (white arrowhead). c1 Detail of the previous figure showing the inner layers composed of well-defined lamellae with small and elongated osteocyte lacunae and the outmost layers with a general lack of bone organization and populated by large and rounded osteocyte lacunae. Polarized light. Magnification $\times 40$; $\times 100$. sumes particular relevance in forensic contexts [47]. For most of the sample studied, however, it was difficult to evaluate the impact of factors such as age in the regular progression of the bone healing, a fact that may affect the estimation of the posttraumatic survival interval. Secondly, histology was useful to distinguish between calluses of fracture origin from other etiologies (e.g. subperiosteal he- matoma, Sk. 119 individual). In this regard, it was also important to further corroborate evidence of secondary complications (e.g. osteomyelitis, Sk. 54 individual), showing that histology may complement the differential diagnosis. Thirdly, it revealed that a gap between the macroscopic and the histological morphology of the bone callus may exist. One can infer that the outer shell is consoli- 
dated, but not that the bone callus is completely healed or remodeled. Accordingly, researchers should be cautious when describing bone lesions of traumatic origin. Finally, histology was useful to determine the sequence of traumatic events in the Sk. 1,196 individual. Moreover, it revealed a set of microstructural changes compatible with age-related osteopenia and, eventually, osteoporosis. It is recommended that future studies should consider a similar approach when trauma lesions and the degree of bone healing are under the scope.

\section{Acknowledgments}

The authors would like to acknowledge Prof. Dr. Ana Luísa Santos and the Museu Bocage (Museu Nacional de História Natural) in Lisbon, in particular the former director, Dr. Maria da Graça Ramalhinho, and the former curator, Dr. Diana Carvalho for giving permission to collect the bone samples. This research was developed within a $\mathrm{PhD}$ project funded by the Fundação para a Ciência e Tecnologia (grants SFRH/BD/36739/2007 and UID/ ANT/00283/2013).

\section{References}

1 World Health Organization (WHO): Preventing injuries and violence: a guide for ministries of health. Geneva, WHO, 2007.

2 Merbs CF: Trauma; in Iscan MY, Kennedy KA (eds): Reconstruction of Life from the Skeleton. New York, Liss, 1989, pp 161-189.

3 Roberts, C: Trauma in biocultural perspective: past, present and future work in Britain; in Cox M, Mays S (eds): Human Osteology in Archaeology and Forensic Science. London, Greenwich Medical Media, 2000, pp 337-356.

4 Roberts C, Manchester K: The Archaeology of Disease. Stroud, Sutton Publishing, 2005.

5 Kilgore L, Jurmain R, Van Gerven D: Palaeoepidemiological patterns of trauma in a medieval Nubian skeletal population. Int J Osteoarchaeol 1997;7:103-114.

6 Glencross B, Stuart-Macadam P: Childhood trauma in the archaeological record. Int J Osteoarchaeol 2000;10:198-209.

7 Standen VG, Arriaza B: Trauma in the preceramic coastal populations of Northern Chile: violence or occupational hazards? Int J Osteoarchaeol 2000;112:239-249.

8 Judd M: Ancient injury recidivism: an example from the Kerma period of ancient Nubia. Int J Osteoarchaeol 2002;12:89-106.

9 Dawson L, Levy TE, Smith P: Evidence of interpersonal violence at the chalcolithic village of Shiqmin (Israel). Int J Osteoarchaeol 2003; 13:115-119.

10 Judd M: Trauma in the city of Kerma: ancient versus modern injury patterns. Int J Osteoarchaeol 2004; 14:34-51.

11 Scott RM, Buckley HR: Biocultural interpretations of trauma in two prehistoric Pacific Island populations from Papua New Guinea and the Solomon Islands. Am J Phys Anthropol 2010;142:509-518.

12 Lessa A: Daily risks: a biocultural approach to acute trauma in pre-colonial coastal populations from Brazil. Am J Phys Anthropol 2011; 21:159-172.

13 Fibiger L, Ahlström T, Bennike P, Schulting RJ: Patterns of violence-related skull trauma in Neolithic Southern Scandinavia. Am J Phys Anthropol 2013;150:190-202.
14 Gordón F: Bioarchaeological patterns of violence in North Patagonia (Argentina) during the late Holocene. Implications for the study of population dynamics. Int J Osteoarchaeol 2015;25:625-636

15 Brickley M: Rib fractures in the archaeological record: a useful source of sociocultural information? Int J Osteoarchaeol 2006; 16:6175.

16 Domett KM, Tayles N: Adult fracture patterns in prehistoric Thailand: a biocultural interpretation. Int J Osteoarchaeol 2006;16: 185-199.

17 Djurić MP, Roberts CA, Rakočević ZB, Djonić DD, Lešić AR: Fractures in late medieval skeletal populations from Serbia. Am J Phys Anthropol 2006;130:167-178.

18 Mays SA: A palaeopathological study of Colles' fracture. Int J Osteoarchaeol 2006; 16:415428.

19 Matos V: Broken ribs: paleopathological analysis of costal fractures in the Human Identified Skeletal Collection from the Museu Bocage, Lisbon, Portugal (late 19th to middle 20th centuries). Am J Phys Anthropol 2009; 140:25-38.

20 Šlaus M, Novak M, Bedić Ž, Strinović D: Bone fractures as indicators of intentional violence in the eastern Adriatic from the antique to the late medieval period (2nd-16th century $\mathrm{AD}$ ). Am J Phys Anthropol 2012;149:26-38.

21 Bennike P: Trauma; in Pinhasi R, Mays S (eds): Advances in Human Paleopathology. Chichester, Wiley, 2008, pp 309-328.

22 Buikstra JE, Ubelaker D: Standards for data collection from human skeletal remains. Proceedings of a Seminar at the Field Museum of Natural History. Arkansas, Archaeological Survey Research Series 44, 1994.

23 Roberts C: Trauma and treatment in the British Isles in the historic period: a design for multidisciplinary research; in Ortner DJ, Aufderheide AC (eds): Human Paleopathology: Current Syntheses and Future Options. Washington, Smithsonian Institution Press, 1991, pp 225-240.

24 Ortner D: Identification of Pathological Conditions in Human Skeletal Remains. Amsterdam, Academic Press, 2003.
25 Waldron T: Paleopathology. Cambridge, Cambridge University Press, 2009.

26 Chhem R, Saab G, Brothwell D: Diagnostic paleoradiology for paleopathologists; in Chhem R, Brothwell D (eds): Paleoradiology: Imaging Mummies and Fossils. Berlin, Springer, 2008, pp 73-118.

27 Lovell N: Trauma analysis in paleopathology. Yearb Phys Anthropol 1997;40:139-170.

28 Martin D: Bone histology and paleopathology: methodological considerations; in Ortner D, Aufderheide A (eds): Human Paleopathology: Current Syntheses and Future Options. Washington, Smithsonian Institution, 1991, pp 55-59.

29 Bell L, Piper K: An introduction to palaeohistopathology; in Cox M, Mays S (eds): Human Osteology in Archaeology and Forensic Sciences. London, Greenwich Medical Media, 2000, pp 255-274.

30 Turner-Walker G: The chemical and microbial degradation of bones and teeth; in Pinhasi R, Mays S (eds): Advances in Human Paleopathology. Chichester, Wiley, 2008, pp 3-29.

31 Wright L, Yoder C: Recent progress in bioarchaeology: approaches to the osteologic paradox. J Archaeol Res 2003;11:43-70.

32 Ragsdale B, Lehmer L: A knowledge of bone at the cellular (histological) level is essential to paleopathology; in Grauer A (ed): A Companion to Paleopathology. Malden, Blackwell, 2012, pp 227-249.

33 Cardoso HF: Brief communication: the Collection of Identified Human Skeletons housed at the Bocage Museum (National Museum of Natural History), Lisbon, Portugal. Am J Phys Anthropol 2006;129:173-176.

34 FitzGerald C, Saunders S: Preparing undecalcified ground tooth sections. Anthropology hard tissue and light microscopy laboratory. Hamilton, McMaster University, 2007.

35 Schultz M: Paleohistopathology of bone: a new approach to the study of ancient diseases. Yearb Phys Anthropol 2001;116:106-147.

36 Schultz M: Light microscopic analysis in skeletal paleopathology; in Ortner D (ed): Identification of pathological conditions in human skeletal remains. Amsterdam, Academic Press, 2003, pp 73-107. 
37 Schultz M: Light microscopic analysis of macerated pathologically changed bones; in Crowder C, Stout S (eds): Bone Histology: An Anthropological Perspective. Boca Raton, CRC Press, 2012, pp 253-296.

38 Lazenby R, Pfeiffer S: Effects of a nineteenth century below-knee amputation and prosthesis on femoral morphology. Int J Osteoarchaeol 1993;3:19-28.

39 Katzenberg A, Lovell N: Stable isotope variation in pathological bone. Int J Osteoarchaeol 1999;9:316-324.

40 Schultz M: Microscopic investigation in fossil Hominoidea: a clue to taxonomy, functional anatomy, and the history of diseases. Anat Rec 1999;257:225-232.

41 Blondiaux G, Blondiaux J, Secousse F, Cotton A, Danze PM, Flipo RM: Rickets and child abuse: the case of a two-year-old girl from the 4 th century in Lisieux (Normandy). Int J Osteoarchaeol 2002;12:209-215.

42 Kuhn G, Schultz M, Müller R, Rühli F: Diagnostic value of micro-CT in comparison with histology in the qualitative assessment of historical human postcranial bone pathologies. Homo 2007;58:97-115.

43 Rühli F, Kuhn G, Evison R, Müller R, Schultz $\mathrm{M}$ : Diagnostic value of micro-CT in comparison with histology in the qualitative assessment of historical human skull bone pathologies. Am J Phys Anthropol 2007;133:10991111.

44 Van der Merwe A, Maat G, Steyn M: Ossified haematomas and infectious bone changes on the anterior tibia: histomorphological features as an aid for accurate diagnosis. Int J Osteoarchaeol 2010;20:227-239.

$45 \mathrm{Wu}$ XJ, Schepartz L, Trinkaus E: Antemortem trauma and survival in the late Middle Pleistocene human cranium from Maba, South China. Proc Natl Acad Sci USA 2011;108: 19558-19562.

46 Steyn M, De Boer HH, Van der Merwe AE Case report: cranial trauma and the assessment of posttraumatic survival time. Forensic Sci Int 2014;244:e25-e29.
47 De Boer H, van der Merwe A, Hammer S, Steyn M, Maat G: Assessing post-traumatic time interval in human dry bone. Int J Osteoarchaeol, 2015;25:98-109.

48 Maat G: 2008, case study 5.3: dating of fractures in human dry bone tissue - the Berisha case; in Kimmerle EH, Baraybar JP (eds): Skeletal Trauma: Identification of Injuries Resulting from Human Rights Abuse and Armed Conflict. Boca Raton, Taylor \& Francis, pp 245-254.

49 Maat G, Huls N: Histological fracture dating of fresh and dried bone tissue; in Bilo RAC, Robben SGF, van Rijin RR (eds): Forensic Aspects of Pediatric Fractures: Differentiating Accidental Trauma from Child Abuse. Berlin, Springer, 2010, pp 194-201.

50 Sfeir C, Ho L, Doll B, Azari K, Hollinger J: Fracture repair; in Lieberman J, Friedlaender G (eds): Bone Regeneration and Repair: Biology and Clinical Application. New Jersey, Humana, 2005, pp 27-44.

51 Bielby R, Jones E, McGonagle D: The role of mesenchymal stem cells in maintenance and repair of bone. Injury 2007;38:S26-S32.

52 Aufderheide A, Rodríguez-Martín C: The Cambridge Encyclopedia of Human Paleopathology. Cambridge, Cambridge University Press, 1998.

53 Urist MR, McLean F: Calcification and ossification. I. Calcification in the callus in healing fractures in normal rats. J Bone Joint Surg Am 1941;23:1-16.

54 Ferguson C, Alpern E, Miclau T, Helms J: Does adult fracture repair recapitulate embryonic skeletal formation? Mech Dev 1999;87: 57-66.

55 Arican M, Ortatatll M, Yigitarslan K, Ceylan C: Osteogenic ability of free perichondreal autografts in canine tibial defects: an experimental study. J Exp Anim Sci 2003;42:203217.

56 Bullough P: Orthopaedic pathology. Maryland Heights, Mosby/Elsevier, 2010.

57 Gerstenfeld LC, Alkhiary YM, Krall EA, Nicholls FH, Stapleton SN, Fitch JL, Bauer M, Kayal R, Graves DT, Jepsen KJ, Einhorn TA: Three-dimensional reconstruction of fracture callus morphogenesis. J Histochem Cytochem 2006;54:1215-28.
58 Ayoub A, Challa SR, Abu-Serriah M, McMahon J, Moos K, Creanor S, Odell E: Use of a composite pedicled muscle flap and rhBMP-7 for mandibular reconstruction. Int J Oral Maxillofac Surg 2007;36:1183-1192.

59 Urist MR, Johnson RW: Calcification and ossification. IV. The healing of fractures in man under clinical conditions. J Bone Joint Surg Am 1943;25:375-426.

60 Liu Y, Manjubala I, Schell H, Epari DR, Roschger P: Size habit of mineral particle in bone and mineralized callus during bone healing in sheep. J Bone Miner Res 2010;25: 2029-2038.

61 von Hunnius, T, Roberts C, Boylston A, Saunders S: Histological identification of syphilis in pre-Columbian England. Am J Phys Anthropol 2006;129:559-566.

62 Adler CP: Bone Diseases: Macroscopic, Histological and Radiological Diagnosis of Structural Changes in the Skeleton. Berlin, Springer, 2000

63 Guttentag A, Salwen J: Keep your eyes on the ribs: the spectrum of normal variants and diseases that involve the ribs. Radiographics 1999; 19:1125-1142.

64 Paine R, Brenton B: Dietary health does affect histological age assessment: an evaluation of Stout and Paine (1992) age estimation equation using secondary osteons from the rib. J Forensic Sci 2006;51:489-492.

65 Martin R, Correa P: Bone quality and osteoporosis therapy. Arq Bras Endocrinol Metabol 2010;54:186-199.

66 Brickley M, Ives R: The Bioarchaeology of Metabolic Bone Diseases. Oxford, Academic Press, 2008

67 Islam O, Soboleski D, Symons S, Davidson LK, Ashworth MA, Babyn P: Development and duration of radiographic signs of bone healing in children. AJR Am J Roentgenol 2000;175:75-78.

68 Prosse I, Maguire S, Harrison S, Mann M, Sibert J, Kemp A: How old is this fracture? Radiologic dating of fractures in children: a systematic review. AJR Am J Roentgenol 2005 184:1282-1286. 